\title{
From Motherhood Penalties to Husband Premia: The New Challenge for Gender Equality and Family Policy, Lessons from Norway ${ }^{1}$
}

\author{
Trond Petersen \\ University of California, Berkeley \\ Andrew M. Penner \\ University of California, Irvine \\ Geir Høgsnes \\ University of Oslo
}

\begin{abstract}
Given the key role that processes occurring in the family play in creating gender inequality, the family is a central focus of policies aimed at creating greater gender equality. We examine how family status affects the gender wage gap using longitudinal matched employeremployee data from Norway, 1979-96, a period with extensive expansion of family policies. The motherhood penalty dropped dramatically from 1979 to 1996. Among men the premia for marriage and fatherhood remained constant. In 1979, the gender wage gap was primarily due to the motherhood penalty, but by 1996 husband premia were more important than motherhood penalties.
\end{abstract}

\section{INTRODUCTION}

By the end of the 20th century it had become abundantly clear that the processes unfolding in the family are a core, if not the core, obstacle to achieving gender equality in the workplace (Williams 2010). For men, marriage and to

\footnotetext{
${ }^{1}$ Parts of this article were presented at the 2007 annual meeting of the American Sociological Association in New York City, at the 2013 annual meeting of the Swiss Sociolog-

(C) 2014 by The University of Chicago. All rights reserved. 0002-9602/2014/11905-0005\$10.00
} 
some extent children have positive effects on wages and careers (Rodgers and Stratton 2010). For women, the reverse is the case; there are small differentials for marital status but large penalties to having children (Budig and England 2001). Family thus pulls in opposite directions for men and women: helping wages and careers for one sex, detrimental for the other, and jointly increasing the gap between men and women.

Analyses of gender equality at work should therefore focus on this family gap and the interrelationship between family and the workplace (e.g., Williams 2010). This claim has been a staple of feminist writings for 40 years, succinctly summarized by Gerson (1985, p. 231): "The conflicts and dilemmas women face will not diminish, despite women's changing social position, until the costs and rewards of working and parenting are more equally distributed by gender." Or as Hewlett (2002, p. 136) comments almost 20 years later: "Increasingly, women earn less than men because of the unequal impact of family responsibilities."

Against this background we address three puzzles in increasing order of importance with respect to the family gap in wages. Our first puzzle concerns the extent to which the family wage gap arises in the same occupation in the same establishment (i.e., same job), with married men and fathers earning more than single and childless men, and mothers earning less than childless women. We assess whether employers pay differentially according to marital and parental status (i.e., unequal pay for equal work). A leading hypothesis would be that there is equal pay for equal work by family status, since there appears to be close to equal pay for equal work by gender status in the United States and Scandinavia (e.g., Groshen 1991; Petersen and Morgan 1995; Petersen et al. 1997). Alternatively one could plausibly conjecture unequal pay for equal work by family status given the salience of family for workplace gender inequality (e.g., Budig and England 2001; Correll, Benard, and Paik 2007; Williams 2010, p. 28).

ical Association at the University of Bern, and at seminars at Stanford University, MIT, Harvard University, Yale University, Columbia University, University of California, Berkeley, and University of Agder. Several meeting and seminar participants made useful comments for which we are grateful, and, in particular, we thank Jim Baron. We also thank the AJS reviewers and Anne Lise Ellingsæter, Alex Janus, and Ragnhild Kitterød for extensive comments, as well as Erling Barth, Lars Gulbrandsen, Arnlaug Leira, Lars Mjøset, and Gerd Vollset for answering inquiries, and Lynn Prince Cooke for pointing out an error. We thank Arne Kristian Aas and Roy A. Nielsen for research assistance.

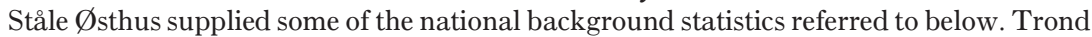
Petersen is grateful for financial support from the Institute for Research on Labor and Employment at the University of California, Berkeley, and from the W. E. Upjohn Institute for Employment Research in Kalamazoo, Michigan, and all three authors are grateful for financial support from the Norwegian Research Council and from the Norwegian Ministry of Children and Equality. Direct correspondence to Trond Petersen, Department of Sociology, 410 Barrows Hall, University of California, Berkeley, California 94720.E-mail: trond@berkeley.edu 
Our second puzzle concerns the role of sorting of employees by family status on occupations and establishments for the size of wage penalties and premia. The leading hypothesis here follows as a corollary to our first puzzle. If there is equal pay for equal work but still large overall pay differentials by family status, then it is the sorting on occupations and establishments that accounts for the differentials, which may arise from employee productivity, employee choices, or from discrimination in hiring or promotion.

Our third puzzle, and ultimately our core errand, concerns the role of family policies in ameliorating the gender wage gap. The central policies are paid parental leave (with a portion reserved for fathers), subsidized child care, tax and cash benefits for children, and availability of flexible hours and access to part-time employment. These policies can shift the incentives and the feasibility for being active in market work for both men and women, and thus affect family adaptations. We assess how the premia and penalties for men and women evolved during a period in which significant family policies were unrolled. As we elaborate below, there is much disagreement between scholars on the effects of such policies, and no generally agreed-upon hypothesis can be put forward.

To address these puzzles we use matched employer-employee data from Norway in the period 1979-96, a country in the family-friendly corner of the world at the forefront of family policies. The matched aspect of the data allows us to address the first two puzzles, providing novel and crucial empirical angles, by documenting where the premia and penalties arise, in wage setting within jobs or in how employees are sorted on occupations, employers, and jobs. The longitudinal aspect of the data from a Scandinavian country allows us to address the third puzzle, the potential role of family policies for changes in the premia and penalties during a period in which many new policies were introduced. The case thus offers an instructive research site.

Behind these three puzzles we find important public policy questions, which our analyses may inform but not unambiguously answer, as elaborated below. If the core problem for the family gap is differential treatment by employers, then more vigorous enforcement of existing antidiscrimination legislation would be the appropriate policy tool. In contrast, if employers are not the main culprit, but the core problem is rather the adaptations men and women make in the spheres of family and work (e.g., from differential household-division of labor and preferences for different lifestyles), the policy implications are different. The appropriate response would be to expand family policies and aim for further cultural changes in the way families function, both of which pose more complex challenges in that families and family cultures are harder to regulate than employers. The question then arises as to whether family policies have had effects in settings where they have been tried on a large scale. Nowhere has this been more the case 
than in Scandinavia: major policies to reinvent the family and its relationship to work were rolled out over the last 20-30 years. ${ }^{2}$ These policies aimed principally at making it easier to combine family and career but also at the internal organization of the family, hoping to create a more equal division of household labor and caring for children. But have the policies worked? Have they led to one of their goals, to facilitate employment and careers for parents?

The answer to the question of policy success is far from obvious, and scholars disagree on the extent to which Scandinavian-style family policies are desirable in the first place and whether they have had their intended effects. Some scholars argue that the Scandinavian (and Nordic) countries offer the "blueprint" for gender-equalizing family policies (e.g., Gornick and Myers 2009, p. 18), a position found among many U.S. feminists who argue for policies aimed at achieving equality between men and women in how they allocate time to market, household, and child-care work. Other scholars are skeptical. Bergmann (2009, p. 70) argues that Scandinavianstyle policies have many negative effects on female careers. Orloff (2009, p. 131) questions the goal of gender symmetry in market and housework and does so especially in the U.S. context (p. 148) where there may be too much diversity in lifestyles for such goals to be plausible. Hakim (2000, p. 240) concludes that Scandinavian women have not achieved labor equality in access to top jobs, authority at work, or pay, noting that "some scholars are now concluding that Nordic egalitarian policies have failed" (p. 243).

We intervene in these debates by focusing on whether Scandinavianstyle family policies have succeeded in one of their stated goals, to increase gender equality at work by reducing the motherhood penalty and hence the gender wage gap (Leira 2002, pp. 94, 105). Assessing the broader desirability of the policies is a task beyond our goals and in the end better suited for normative rather than empirical analysis.

It is important to note that, for our first and second puzzles, we assess whether the wage differences arising from family situation stem from unequal pay for equal work or whether they stem from differential sorting of employees on occupations and establishments. We do not assess whether these differences are due to discrimination from employers (in wages, hiring, and promotions), from employee productivity and qualifications, or from employee adaptations in terms of effort within a job or with respect

\footnotetext{
${ }^{2}$ The Scandinavian countries are Denmark, Norway, and Sweden, whereas the Nordic region also includes Finland and Iceland as well as the three autonomous territories Faroe Islands, Greenland, and Åland (five countries and three autonomous territories, all members of the Nordic Council). Scholars sometimes count Finland as a Scandinavian country (e.g., Alestalo and Kuhnle 1987), and sometimes refer interchangeably to Denmark, Finland, Norway, and Sweden as Scandinavian or Nordic countries (Ellingsæter and Leira 2006, p. 2).
} 
to where to work when seeking appointments and promotions. Further, with respect to our third puzzle, assessing the precise effects of family policies on the rewards and penalties to family status is difficult, in part because policies work out over many years, in part because they come bundled with other changes, such as in reduced discrimination against women and changes in family culture (e.g., division of household labor, fatherhood norms). But to the extent that the family gap in the labor market decreased over the period analyzed, family policies likely played a key role, though its precise impact may be impossible to disentangle.

We build on two earlier articles using the same data investigating the role of family for wages separately for men and women (Petersen, Penner, and Høgsnes 2010, 2011), addressing a number of additional issues ignored here. ${ }^{3}$ We now offer the culmination of this research by examining what was earlier entirely left out and which in the end forms a key concern in the literature on family and work: the impact of family on the gender gap in wages. By necessity, to make the novel results intelligible, some of the prior results must be restated, though we use new specifications and historical periodizations. But then we go beyond these studies in two crucial directions. First, as mentioned above, we focus on the role of family for the gender wage gap, as opposed to its role separately for the wages of men and women. Second, we focus in detail on the role of family policies for the motherhood penalty and the wage gap by tracing year by year when the major changes in the penalties and the gaps occurred and how the changes matched the changes in family policies, relying on a periodization of years into distinct family policy regimes. The results highlight the possibly incommensurate difficulties that family policies face in contributing to solving gender inequality in the workplace, in that they may reduce some inequalities while leaving other inequalities intact.

\section{SOURCES OF PREMIA AND PENALTIES}

A considerable body of research examines the effects of family on the wages of men, and an equally extensive, though largely separate, literature documents the effects of family on the wages of women. For men the marital premium can be substantial, in the United States up to $15 \%$ (see Rodgers and Stratton 2009), but it is lower in Scandinavia, 6\% or less (see Datta Gupta, Smith, and Stratton 2007). The child premia for men tend to be low,

\footnotetext{
${ }^{3}$ A single article that simultaneously accomplishes the multiple goals of the three separate articles would likely have exhausted even the most patient reader. The articles on men and women had six and four tables, respectively, while the current article has three tables plus a figure. Combining the three into a single article would have required around 10 tables.
} 
at most $2 \%, 5 \%$, and $6 \%$ for families with one, two, or three or more children (see Stratton 2002; Datta Gupta et al. 2007). For women in the United States, there are relatively small marital premia, close to zero and up to $4 \%-6 \%$ at most (e.g., Hundley 2000). The wage penalties for having children are substantial, up to $15 \%-20 \%$ for two or more children, and even $8 \%-10 \%$ after extensive controls for occupation and other variables (e.g., Budig and England 2001; Anderson, Binder, and Krause 2002). Women's marital premia and child penalties are lower in Scandinavia, around 2\%-10\% for two or more children (Harkness and Waldfogel 2003; Davies and Pierre 2005) and even lower in the Danish case (e.g., Datta Gupta and Smith 2002). ${ }^{4}$

The patterns of family premia and penalties have obvious implications for the gender wage gap. Even from a hypothetical initial position of gender wage parity while single and childless, the result is that a substantial wage gap develops as men and women marry and have children. Waldfogel (1998a, p. 533) reports that about 40\%-50\% of the gender wage gap in Great Britain and the United States is due to family status and that another 30\%$40 \%$ of the gap is due to the loss of labor force experience. Harkness and Waldfogel (2003) report gender wage gaps by parental status in seven industrialized countries, finding that the impact of motherhood on the gap is smallest in the Nordic countries (in their study, Finland and Sweden), the countries with the most extensive family policies, and higher in the United Kingdom and the United States.

One central question that has not been addressed in this research is the degree to which differences in wages arise from employers paying unequal wages for the same work depending on family status or whether family status results in employees working in different types of jobs. This is the question of equal pay for equal work in the sense of the U.S. Equal Pay Act of 1963, which pertains to wages for employees in the same occupation in the same establishment (i.e., same job). The results in Budig and England (2001), with extensive controls for occupation, may lead one to hypothesize that there also is unequal pay by family status in the same job. The few pieces of research that compare employees in the same job find differences by family status in hiring and promotions. An audit study reports a negative impact of motherhood status on hiring (Correll et al. 2007). A study of a single company finds that married men are promoted at a higher rate than single men, but that the difference disappears once performance rat-

\footnotetext{
${ }^{4}$ A subset of the results in the two earlier articles investigating the role of family for wages separately for men and women in Norway (Petersen et al. 2011, 2010) will be recast in parts of the analysis section below - with different specifications, slightly different samples, and a different grouping of historical periods. They are hence not discussed above. For the motherhood penalty in Norway, see also Hardoy and Schøne (2008).
} 
ing is controlled (Korenman and Neumark 1991, p. 302). There is as yet no study using large-scale data sets examining the degree to which there also is unequal pay for equal work by family status.

Examining equal pay for equal work requires access to matched employeremployee data. Such data have been used to study the gender wage gap (for the United States, see Groshen 1991; Petersen and Morgan 1995), but not yet for the role of family for the gap. They allow us to compare the wages of employees working in the same occupation in the same establishment. We can assess whether there is different pay at the occupation-establishment (i.e., job) level, that is, whether productivity differences and/or discrimination could have arisen at that level. The absence of a gap at the occupationestablishment level would establish that unequal pay for equal work is not the source of the family gaps in wages. The source would instead be differential sorting of employees by family status into high- and low-paying occupation-establishment units, which could arise from employee productivity, employee adaptations, or from discrimination in hiring or promotion.

Turning to the underlying conceptual questions, in thinking about the mechanisms behind the family gap, a leading explanation for why employers would pay parents and married employees differently from nonparent and single employees proposes that this is due to discrimination (Williams 2010, chap. 2). The claim is that employers consciously favor married men, either as a reflection of societal norms, which stress the value of marriage (taste discrimination), or due to statistical (or error) discrimination, where married men are correctly (or erroneously) seen to be better employees on average and where it is difficult or costly to assess which married and which single men are more productive (Blau, Farber, and Winkler 2010, chap. 7). For women, the effects of marriage are also seen to be positive, whereas motherhood may lead employers to pay them less and to hire and promote them at lower rates. Williams (2010, p. 28) claims that "bias against mothers is the strongest form of gender bias in today's workplace." Additionally there may be nonconscious sources of discrimination, as stressed in much recent psychological, legal, and sociological scholarship (e.g., Greenwald and Krieger 2006), with the same effects as conscious taste and statistical discrimination. We refer to these collectively as the discrimination hypothesis.

Two additional hypotheses have been put forth to explain the premia and penalties to marriage and parenthood (Korenman and Neumark 1992) and have been applied to both sexes, but with different implications. They focus on employees, their characteristics, and their adaptations in response to changes in family status.

According to the selection hypothesis, those who get married and become parents are different from those who do not, and would earn different 
wages and have different careers even in the absence of marriage and children. The idea is that men who get married and have children may be more productive than those who do not, while women who become mothers may be less career oriented than women who choose to remain childless or have few children.

According to the treatment hypothesis, men and women change their workplace behavior upon marriage and parenthood, resulting in changes in productivity (increased for men, decreased for women), which subsequently affects wages and careers. One source of this change is the gendered division of household labor and caring for children, with men putting in more effort at paid work and women more at home.

While the discrimination hypothesis is central to understanding the need for additional antidiscrimination legislation and measures, the selection and treatment hypotheses are important for understanding the potential role of family policies and family culture in changing the gaps.

As discussed in the introduction, in the empirical analysis we adjudicate whether wage differences by family status arise within jobs versus whether they result from different placement across jobs. The analysis does not determine whether differences arise from employer discrimination (in wage setting, hiring, and promotion), from employee selectivity, or from employee choices with respect to effort within job or place to work when seeking appointments and promotions. For example, a within-job motherhood wage penalty may result from discrimination by the employer, from differences in the selectivity of mothers and nonmothers, or from lower work effort as an adaptation to motherhood leading to lower wages, in cases where jobs are paid by productivity. Similarly, differential job placement at hiring and promotion can arise from discrimination, from employee selectivity, or from employee adaptations, for example, if mothers seek jobs with more flexibility and lower pay. But to the extent that one finds equal pay for equal work (no within-job wage gaps), one might reasonably conjecture that there is absence of discrimination at that level, though even this conclusion may be disputed, for example, if mothers are less productive than nonmothers but still receive the same pay, in which case there may be discrimination against nonmothers.

\section{SOURCES OF CHANGE}

\section{Family Policies}

How the family operates and the relationship between family and work are amenable to change from two important sources, family policy and cultural change. We first review four family policies and institutional arrangements that have been identified as important for the family gap (Waldfogel 1998b, 
American Journal of Sociology

pp. 141-45; Dex and Joshi 1999, pp. 655-56; Gornick and Meyers 2003, chap. 8). In doing so we comment on their role in the Norwegian context, where family policies have been considerably more elaborate than in most other countries, though not at the level of Swedish policies. In Norway these policies play out against a fixed background of the Gender Equality Act of 1978, which made discrimination on the basis of sex illegal but did not contain specific legislation protecting parents in employment (similar to the U.S. Equal Pay Act of 1963 and Title VII of the Civil Rights Act of 1964). Parents were, however, protected in a separate Work Environment Act of 1977.

The first major public policy is paid parental leave - maternity and paternity_preferably (for gender equality) with a portion reserved for fathers. In many countries, including those in Scandinavia, this is financed through social insurance (tax contributions paid by all employers and employees regardless of whether they employ parents or are parents). The central cost borne by employers is the prolonged absence of their employees after childbirth; practically all mothers take the leave and increasingly fathers do the same (Gornick and Meyers 2009, p. 39).

Maternity leave allows women to keep their jobs while they take time off to care for children and to keep a portion of their salary. Attractive job matches can be maintained and permanent employment secured. However, lengthy maternity leave can lessen human capital accumulation through loss of work experience and training (for the case of Sweden, see Albrecht, Edin, and Sundström [1999]). Paternity leave provides many of the same benefits for fathers and may lead to a more equal distribution of work in the household and thus lessen the workload on the mother.

In Norway, parental leave was available for 18, 20, and 22 weeks in 1977, 1987 , and 1988, with $100 \%$ pay from 1978. Since 1977 fathers could share the leave, with the exception of the first six weeks, which were reserved for the mother. Between 1988 and 1993 parental leave was increased by a few weeks every year from 22 to 52 weeks at $80 \%$ pay (or 42 weeks at $100 \%$ pay), though compensation for high earners is capped at a maximum amount (Rønsen and Sundström 2002). Effective in 1993, as the first country in the world, four weeks were reserved for the father and six weeks for the mother (Leira 2002, pp. 89, 95). In 1996, 69\% of fathers took paid parental leave and used $7 \%$ of the parental leave days (Leira 2002, pp. 86, 91).

The second major policy is subsidized child care, often publicly provided. This allows mothers to return to work soon after childbirth and results in less loss of human capital. Of some importance here are the opening hours of child-care facilities, which in the United States are long and thus may especially help the careers and earnings of the highly educated. In Scandinavia hours at child-care facilities are short; in Norway they are typically open only between 7-7:30 a.m. and 5 p.m. This may be good for 
children and most parents but does not help careers of parents in many high-paying professional jobs. ${ }^{5}$

In Norway, the percentages of children enrolled in publicly supported child care increased considerably over the period studied: among 1-2 and 36-year-olds from $6.8 \%$ and $32.0 \%$ (1980) to $31.3 \%$ and $61.7 \%$ (1995; see Ellingsæter and Gulbrandsen 2003, table 15, p. 36). Overall, for children 0-6 years old, between 1980 and 1995 the percentages enrolled more than doubled from $20.9 \%$ to $44.3 \%$. There was still a substantial shortage of publicly supported child care for all ages $0-6$, but especially so for $0-1$ - and 1-2-yearolds, in part reflecting the long periods of parental leave offered (especially from 1993). The coverage was much lower than in Denmark and Sweden. The cost of child care during the period was relatively low in Norway (with single parents paying lower fees), though considerably higher than in the other Scandinavian countries (but with significant decreases in prices from 2003). During the 1990 s costs stood at $13 \%$ of average female earnings compared to $22 \%$ in the United States (Waldfogel 1998b, table 2). ${ }^{6}$ Access to child care was not a social right in Norway during the period analyzed but became so in 2009, much later than in the other Scandinavian countries.

A third policy involves the provision of cash benefits and tax breaks for children. These make it easier to have children and may have pronatal effects. Whether they do much for the family gap is less clear. Their impact may in fact be negative, as they may encourage lengthy career breaks, but they can also facilitate employment by making it economically easier to purchase child care. Norway has provided monthly child benefits from birth through age 17 on a restricted basis since 1946 and universally since 1970, with extra allowances for families with children 0-3 years old (1991-93) and 1-3 years old (1994-2002), and with other new policies starting in 1998. Norway also had (and still has) tax benefits, allowing parents to deduct child-care costs similar to but more flexible than the child-care costs parents can deduct in the United States.

A fourth major policy arises in the realm of employment regulation and organizational practices, namely, the availability of part-time jobs and jobs with flexible hours and schedules. Such jobs may facilitate labor-force attachments for mothers, especially of small children. These policies are implemented by employers, but they can be influenced by public policy as well. The tax system is particularly important. Part-time work is often cheaper

\footnotetext{
${ }^{5}$ Hours are similar in Finland ( 7 a.m. to 5 p.m.) but longer in Denmark (7 a.m. to 6 p.m.) and Sweden (6:30 a.m. to 6 p.m.). See Gornick and Meyers (2003, table 7.9, pp. 230-31). ${ }^{6}$ Esping-Andersen (1999, p. 66, table 4.4), however, argues that net costs for child care in the United States are among the lowest internationally, stating that even in the absence of publicly provided child care "the United States offers a superior cost-subsidy mix" and that as a percentage of family income costs are equal to those in Denmark and France and lower than in Sweden.
} 
to provide in Scandinavia than in the United States since benefits such as medical insurance are paid for on a prorated basis, are compulsory, and cover everyone. Employers thus pay a fixed percentage of the employee's received wages, as opposed to paying a fixed premium for a health insurance plan. In the case of Norway, part-time work and flexible hours are and have been widely available; there is no wage penalty to being employed part time; and parents of small children have, under certain conditions, the right to parttime work (regulated by the Work Environment Act of 1977).

The first two policies-parental leave and child care - are important around the period of childbirth and up until school age. The third and fourth policies - financial incentives and flexible employment-have consequences for a longer period. Tax breaks and cash benefits are often given until age 18 for each child. Flexible hours may also be attractive for families with teenage children living at home. The policies are primarily targeted at employees who combine parenthood with full- or part-time careers but are less sensitive to the family adaptations of stay-at-home mothers (see Hakim 2000, chap. 1). ${ }^{7}$

In Norway during the period of our data-following the expansion of parental leave to 20 weeks with $100 \%$ pay in 1978 - changes in family policies divide into three periods: (1) 1979-87, eight years with relatively stable policies, including the first year (1979) the Norwegian Gender Equality Act of 1978 was effective; (2) 1988-93, six years when policies were expanded (especially parental leave, including the four weeks reserved for fathers, but also publicly subsidized child care); and (3) 1994-96, the years following the expansion, with fewer changes in policies.

Although most Scandinavian family policies are gender neutral, their firstorder impact is primarily on mothers, making it easier to combine family and career; female labor-force participation rates are now close to male rates, though with higher rates of part-time work for women. The secondorder impact is on the adjustments fathers make. In passing Norwegian family legislation a goal expressed during parliamentary debates was to change the culture of how families operate in order to create gender equality within the family (Leira 2002, pp. 94-95), which is well captured by the phrase "politicising parenthood" (Ellingsæter and Leira 2006). ${ }^{8}$ One goal

\footnotetext{
${ }^{7}$ There are also externalities of such policies, principally for children, their most important target. Parental leave results in parents spending more time with children, while publicly supported child care results in the opposite. The needs and interests of children can conflict with achieving gender equality (e.g., Presser 1995). But policies can also be beneficial to children, to the extent that it is in their best interest to be cared for by both parents (see, e.g., Gornick and Meyers 2003, chap. 5).

${ }^{8}$ In 1986 the Norwegian government appointed a Committee on Men's Role, led by a future prime minister in four of its five operating years, resulting in the Green Paper (a
} 
was to strengthen the bond between fathers and children, thereby creating entirely new norms for fatherhood and, it is hoped, increasing the welfare of children. Other goals were to create more equality in the division of work at home and hence, it is hoped, more gender equality in the labor market (Leira 2002, chap. 4). ${ }^{9}$ Internationally, Norway-along with Sweden, Canada, and the United States - has one of the most equal divisions of household labor (Hook 2006, fig. 1, p. 650; see also Fuwa 2004, table 2, p. 757), and along with Sweden scores at the top of the Gender Empowerment Measure of the Human Development Report (Fuwa 2004, table 2).

\section{Cultural Transformations}

A second source of change in the family gap comes from broad cultural transformations over the last 40 years concerning the role men take in the family in both household work and caring for children. Cultural changes may also result in pressures to legislate new policies, and policies in turn may lead to changes in culture and, hence, the relationship between family and work. While not the focus in our empirical analysis, it is nevertheless instructive to reflect on these cultural changes, as they were concurrent with changes in family policies and thus are relevant to the interpretation of any changes in family gaps over time.

The first major change is in the distribution of household labor (Bianchi, Robinson, and Milkie 2006). Over the last 40 years in many Western societies - including the United States, Norway, and Scandinavia more generally - men have increased the number of hours they spend doing household chores. Women have conversely decreased their hours. The net effect is that the gender gap in household hours has decreased sharply, as has the total number of household hours. Much of the closing of the gap must be due to cultural changes, but some of it likely is also brought about by necessity through rising female labor-force participation rates.

The second major change is in the institution of fatherhood. Fathers spend more time taking care of children today than 40 years ago (Bianchi

report often used as input when making legal changes) Committee on Men's Role Final Report (NOU 1991). The subsequent legal change - the four-week fatherhood quota in parental leave-was made effective in 1993. The legal changes led to a further Green Paper by another governmentally appointed committee, strikingly titled Daddy Come Home (NOU 1995).

${ }^{9}$ Leira (2002, p. 76) points out that the Scandinavian family policy with a fatherhood quota in parental leave "represents an intervention in the internal arrangements of the family, and in parental negotiations around the organisation of everyday life. It also sets new norms for the 'good' father, and state support for fathercare signals the potentiality for far-reaching change in the way fathers and mothers negotiate employment and childcare." 
American Journal of Sociology

et al. 2006, chap. 4). Here the trend in many countries has been the opposite of that in housework: total parental time devoted to children has gone up. The role of family policies in causing these changes is difficult to assess, but some portion of changes is clearly unrelated to such policies since changes have occurred at a significant scale also in countries with limited family policies.

These remarkable cultural transformations are well documented by time-use statistics. In the United States the average household work done by married mothers decreased from 34.5 to 19.4 hours per week between 1965 and 2000, while among married fathers it increased from 4.4 to 9.7 hours, an increase in the share done by men from $13 \%$ to $33 \%$ (Bianchi et al. 2006, p. 93, table 5.1). In the same period men more than doubled the time spent on child care and women increased it by about $20 \%$, with similar changes in many other rich countries (Bianchi et al. 2006, p. 64, table 4.1, pp. 159-60, figs. 9.1-9.2). With respect to the combined hours spent on household tasks and caring for children, the percentage of hours done by men increased from $20 \%$ to $28 \%$ to $38 \%$ from 1975 to 1985 to 2000 , with similar increases in Norway, from $30 \%$ to $35 \%$ to $38 \%$ from 1980 to 1990 to 2000 (Hook 2006, fig. 1B, p. 650; Kitterød and Pettersen 2006). For the total hours on paid and unpaid work, there was in the United States practically no gender difference among married parents from 1965 to 2000, though there was an increase for both sexes in the total hours (Bianchi et al. 2006, p. 55, table 3.4). A central reason for the relatively equal distribution of domestic tasks in Scandinavia and the United States is that the amount of household work done by women is internationally very low, the lowest (Norway) and the fourth lowest (United States) of 34 countries (Knudsen and Wærness 2008, table 2, p. 103). Parity in housework and taking care of children has yet to be achieved, but the changes are substantial.

\section{DATA}

To address the questions outlined above we use matched employeremployee data on all white-collar employees in central parts of the private sector of the Norwegian economy in the period 1979-96. The data were collected from individual-level records kept by the establishments and compiled by the Norwegian Central Bureau of Statistics and the main employer's association in Norway, the Confederation of Business and Employers (NHO). Norwegian employers are bound by law to collect and report the data (e.g., Central Bureau of Statistics 1991, pp. 120-23). The data are used in wage bargaining and economic planning and should be more reliable than information from survey respondents on pay rates, hours worked, and 
occupation but, as explained below, less reliable for the measurement of labor force experience and cohabitation status. ${ }^{10}$

During the period of our study (1979-96) Norway had a gender wage gap comparable to the other Scandinavian countries - among private sector employees women earned about $16 \%$ less than men in 1996. In the data we use, women earned $30.5 \%$ less than men at beginning of the period (1980), 26.0\% less in the middle (1988), and 20.0\% less at the end (1996).

The matched employer-employee data over an 18-year period allow us to (1) compare employees working in the same occupation in same establishment, where comparisons are made between single, married, previously married, and those with and without children; (2) assess the role of sorting into occupations and occupation-establishment units; and (3) trace changes over time as family policies were unrolled.

We follow the establishments and their employees from year to year and have information on 3.9 million person-years. We restricted the analysis to employees 20-50 years old, yielding about 2.8 million person-years. ${ }^{11}$ On an annual basis, we use information on 147,027-193,197 employees, 11,364-19,500 establishments, 488-608 occupations, and 59,042-78,091 occupation-establishment units. For each employee we have information on sex, occupation, age, part- versus full-time status, contractual hours worked, and monthly earnings from work on contracted hours, which excludes wages on overtime hours. The data have been matched to register data from the Central Bureau of Statistics, providing detailed information on educational attainment (length and type, four-digit code), family or civil status (eight statuses), number and ages of biological and adopted children. This provides complete educational, marital, and parental histories for the period studied.

These data on white-collar employees cover all occupational groups, such as technical, professional, administrative, and managerial employees,

\footnotetext{
${ }^{10}$ The data are quite complete. For example, for the year 1992 we have complete data on $84 \%$ of the establishments and $94 \%$ of their white-collar employees.

${ }^{11}$ The restriction to ages 20-50 was done for several reasons, related primarily to considerations with respect to female childbearing and careers. Women who get pregnant at age 18 and give birth at age 19 would rarely enter the labor market before age 20. Many employees younger than 20 will be between employment and education, and below age 18 there are typically lower wage scales for each position, and any results would be of limited interest. The upper bound at age 50 we selected because childbearing usually stops around age 40 , and the key aspects of regular careers have been launched before age 50. For men, we make the same age restrictions to make them comparable to women. We have experimented with a variety of age restrictions, including using an upper bound on ages 45 and 40. The key patterns we report are robust to those changes in age restrictions. Practically all studies that investigate the motherhood wage penalty make age restrictions, with much variation between studies, usually dictated by the data used. For example, Anderson et al. (2002), Budig and England (2001), and Waldfogel (1998a) include ages 14-44, 17-38, and 24-44, respectively.
} 
with a few exceptions: CEOs, top editors of newspapers, secretaries to the editors of newspapers, and journalists. The occupational code is detailed, with 488, 511, and 608 occupations in 1981, 1989, and 1996. The restriction of analyses to white-collar employees is made in part because that is where most private-sector female employment is found and in part because that is where the larger gender wage gaps are found; this probably leads to results with somewhat larger motherhood penalties than if additional blue-collar employees (see Petersen et al. 1997) as well as employees in the public sector had been included. ${ }^{12}$

The analysis includes five broad sectors of the Norwegian economy (in the private sector): (a) manufacturing, oil extraction, mining, quarrying, transportation, storage, communication, and various other industries; $(b)$ business services; $(c)$ retail and wholesale trade; $(d)$ banking; and $(e)$ insurance. The sectors are broadly representative and account for roughly $25 \%$ of all employees in the Norwegian economy.

From the contractual monthly earnings and contractual hours worked we computed the hourly wage, which then refers to hourly wages paid on regular work hours, hence not mixing pay on regular and overtime hours. This is important since a central goal of the analysis is to assess whether employers pay differently by sex and family status, in which case we need to measure the pay rate on regular hours. Five marital statuses are distinguished: single, married, separated, divorced, and widowed. Among the married, separated, and divorced, we include a few hundred employees in same-sex unions that were intact ("married"), "separated," and "divorced"; these are legal categories in Norway. Excluding these cases does not affect the results. We coded three dummy variables for number of children ages 20 or younger: for one, two, or three or more such children. ${ }^{13} \mathrm{We}$ experimented with a number of different codings for the child variables, such as number of children below age 6 , between 6 and 15, and so forth. The alternative codings make no substantive difference for the conclusions arrived at in the analyses. We also control for potential labor force experience, imputed as age minus years of education minus 7 .

Table 1 provides descriptive statistics. To simplify presentation, we report the annual averages (for the wages for three separate years) within the

\footnotetext{
${ }^{12}$ Among blue-collar employees, the gender wage gap was rather small already by 1990 . This reflects in part the unionized wage scales found among blue-collar workers with negotiated wages for each occupation that to a large extent are followed across establishments. The gender wage gap is also smaller among public sector employees, where women are more heavily represented than in the private sector. The sex segregation by sector explains part of the overall gender wage gap in Norway.

${ }^{13}$ The impact of having children on wages and careers clearly lasts beyond the period of children living at home through lost experience and opportunities. But for the questions addressed here, and in most of the research on the motherhood penalty, it is the period with children at home that is the focus.
} 
TABLE 1

Descriptive Statistics for the Three Periods, Separately for Men and Women

\begin{tabular}{|c|c|c|c|c|c|c|}
\hline & \multicolumn{2}{|c|}{$1979-87$} & \multicolumn{2}{|c|}{$1988-93$} & \multicolumn{2}{|c|}{$1994-96$} \\
\hline & Men & Women & Men & Women & Men & Women \\
\hline \multicolumn{7}{|l|}{ Marital status (\%): } \\
\hline Single $\ldots \ldots \ldots \ldots$ & 24.0 & 41.1 & 28.1 & 39.2 & 31.3 & 36.6 \\
\hline Married . . . . . . . . & 70.7 & 48.0 & 64.9 & 47.8 & 60.7 & 49.5 \\
\hline Divorced . . . . . . & 3.4 & 7.4 & 4.7 & 9.4 & 5.7 & 10.6 \\
\hline Widowed . . . . . . . & .2 & .9 & .2 & .7 & .2 & .7 \\
\hline Separated $\ldots \ldots \ldots$ & 1.8 & 2.6 & 2.1 & 2.9 & 2.0 & 2.7 \\
\hline Ever married . . . . . & 90.3 & 83.9 & 86.0 & 80.5 & 81.7 & 77.9 \\
\hline \multicolumn{7}{|l|}{ Parental status (\%): } \\
\hline No children ....... & 31.3 & 56.3 & 33.7 & 52.4 & 34.4 & 47.8 \\
\hline $\begin{array}{l}\text { One child } 20 \text { or } \\
\text { under } \ldots \ldots \ldots\end{array}$ & 21.3 & 22.3 & 23.4 & 25.9 & 23.0 & 25.6 \\
\hline $\begin{array}{l}\text { Two children } 20 \text { or } \\
\text { under } \ldots \ldots \ldots \ldots\end{array}$ & 33.7 & 16.8 & 30.8 & 18.4 & 29.5 & 22.0 \\
\hline $\begin{array}{l}\text { Three }+ \text { children } 20 \\
\text { or under . . . . . . }\end{array}$ & 13.7 & 4.7 & 12.1 & 3.3 & 13.2 & 4.6 \\
\hline Ever have & & & & & & \\
\hline children $\ldots \ldots \ldots$ & 88.5 & 82.1 & 87.0 & 83.2 & 84.3 & 81.8 \\
\hline \multicolumn{7}{|l|}{ Wages: } \\
\hline Mean & 55.9 & 38.9 & 106.0 & 78.5 & 147.2 & 117.8 \\
\hline SD $\ldots \ldots \ldots \ldots$ & 17.2 & 8.8 & 34.3 & 20.4 & 47.9 & 32.0 \\
\hline \multicolumn{7}{|l|}{$\begin{array}{l}\text { Potential labor force } \\
\text { experience: }\end{array}$} \\
\hline Mean $\ldots \ldots \ldots \ldots$ & 15.6 & 14.1 & 16.5 & 15.4 & 16.9 & 16.7 \\
\hline $\mathrm{SD} \ldots \ldots \ldots \ldots$ & 8.4 & 9.4 & 8.5 & 9.5 & 8.5 & 9.3 \\
\hline \multicolumn{7}{|l|}{ Education: } \\
\hline Mean . . & 3.6 & 2.0 & 4.2 & 2.8 & 4.7 & 3.4 \\
\hline $\mathrm{SD} \ldots \ldots \ldots \ldots$ & 3.5 & 2.1 & 3.6 & 2.8 & 3.7 & 3.1 \\
\hline$N$ person-years $\ldots \ldots$ & 858,774 & 446,942 & 705,943 & 394,434 & 340,208 & 186,086 \\
\hline$N$ individuals $\ldots \ldots \ldots$ & 228,951 & 160,900 & 200,244 & 126,291 & 158,951 & 91,048 \\
\hline$N$ occupations $\ldots \ldots$. & 581 & 538 & 608 & 564 & 593 & 548 \\
\hline$N$ establishments . . . . & 28,484 & 29,867 & 25,781 & 24,867 & 17,565 & 16,431 \\
\hline $\begin{array}{l}N \text { occupation- } \\
\quad \text { establishments } \ldots .\end{array}$ & 158,929 & 96,152 & 127,441 & 83,026 & 78,503 & 50,688 \\
\hline
\end{tabular}

NoтE.-For wages, we computed the averages and standard deviations for the second year (1980) in the first period, for the first year (1988) in second period, and for the last year in the third period (1996), yielding corresponding three annual wages (and implied wage gaps) spaced eight years apart. The statistics for the other variables were first computed separately for each year, and then an average of the annual averages was taken within each of the three periods (1979-87, 1988-93, and 1994-96). We computed the distributions (in percent) on marital status and parenthood status and means and standard deviations for educational attainment and potential labor force experience. On average, male and female employees were observed for nine and eight years, respectively. The last five lines of the table give for each of the three periods (1) the number of individual-years, (2) the number of distinct individuals, (3) the number of occupations, (4) the number of establishments, and (5) the number of occupationestablishment units. The total number of individual-years $=2,932,387$; occupation-years $=$ 9,188; establishment-years $=284,771$; and occupation-establishment years $=1,172,810$. Excluding the years 1979, 1980, 1982 (the three years when our data are not complete), the average, the minimum, and maximum number of observations per year are: for individuals, Mean = 175,330, Min = 147,027, Max = 193,197; occupations, Mean = 546, Min = 488, Max =608; establishments, Mean $=17,067$, Min $=11,364$, Max $=19,500$; and occupation-establishments, Mean $=70,150, \operatorname{Min}=59,941, \operatorname{Max}=78,091$. 
three family policy periods identified earlier: (1) 1979-87, (2) 1988-93, and (3) 1994-96.

About $50 \%$ of the women were married in any given year (with higher percentages for men), and $40 \%$ were single. The percentage of men with no children stayed relatively stable from 1979 to 1996 (increased from $31.3 \%$ to $34.4 \%$ ), while for women it declined from $56.3 \%$ to $47.8 \%$. About $34 \%$ of the women were single with no children and $6 \%$ were single with children (numbers not reported in the table). ${ }^{14}$ On average, male and female employees are observed for nine and eight years, respectively.

In addition to changes in legislation and policies, the historical period analyzed saw significant changes in female employment. Of particular importance are changes in the participation of women in the workforce and, among women, of mothers and married women. This raises concerns over whether women and mothers have become more or less select over the period. If the composition of mothers and nonmothers in our data changed over the period, this could by itself account for changes in the motherhood wage penalty. About $25 \%$ of the women in our data left every year for other sectors or for nonemployment (with about $20 \%$ of the men doing so). Early in the period, mothers were more likely to leave than nonmothers, by 1-5 percentage points. Later in the period, mothers were less likely to leave than nonmothers, by $1-5$ percentage points. We found similar differences and changes in differences by marital status. The differences in years of education of mothers relative to nonmothers were also very small over the period. It thus appears that the mothers did not become more select during the period; if anything, they became less so.

Our data suffer from one significant weakness. We do not know which employees are cohabiting. For the employees who are recorded as single (i.e., not yet married), some are truly single, others are cohabiting. Cohabitation is important in Norway, especially among younger cohorts, and increased over the period 1980-2000 (Noack 2001). In 1990, about $58 \%$ of Norwegian men ages 20-66 were married and another 6\% were cohabiting, with the remaining $36 \%$ being single; percentages for women are similar. Assuming that the ratio of singles to cohabitors is the same in our data as in the population, among men the $29.4 \%$ (in 1994-96) recorded as single really consists of $25 \%$ singles and $4 \%$ cohabitors, while among women $32 \%$ would be single and $5 \%$ would be cohabiting. While we are not aware of any Norwegian studies investigating wage premia for cohabitors, the male cohabitation premium in Sweden was 3\% and in Denmark 2\% (Datta Gupta

\footnotetext{
${ }^{14}$ The percentages of women who were mothers and/or married were the same in our data as in other sectors, although the percentage female was $35 \%$ in our data (and stayed fairly stable over the period) versus $45 \%$ (1990) among all employees in the Norwegian economy, with lower percentages female in the private than the public sector.
} 
and Smith 2002; Richardson 2000), while the female cohabitation premium in Denmark is about 1\% (Datta Gupta and Smith 2002). ${ }^{15}$

Some biases arise from this misclassification, as documented by Cohen (2002) for men using U.S. data. If cohabitors enjoy wage premia similar to married employees, we will overestimate the wages of single employees, while still correctly estimating the wages of married employees, and thus underestimating the wage differential (i.e., the marital premium). To the extent that cohabiting employees are more like single employees in their economic success, there is no problem. ${ }^{16}$

\section{METHODS}

The data have a unique multilevel structure. The key feature for our purposes is that in a given year we can use fixed-effects models to compare employees within the same establishments, occupations, and occupationestablishment units.

We report a sequence of four regression equations predicting hourly wages. We include independent variables for education and potential labor force experience plus dummy variables for marital status and the number of children 20 years or younger. The first equation controls neither for the establishments where employees work nor for their occupations, the second controls for the establishment (workplace), the third for the occupation, and the fourth for the occupation-establishment unit (i.e., job). The second, third, and fourth specifications are estimated using fixed-effects models with fixed effects (i.e., dummy variables) for the establishment, occupation, and the occupation-establishment unit, respectively. ${ }^{17}$ The four specifications will be referred to as the Population, Establishment, Occupation, and Occupation-Establishment estimators. The appendix provides more detailed information.

Our first empirical puzzle - about equal pay for equal work by family status - is answered by the occupation-establishment coefficients. Our sec-

${ }^{15}$ Given that the role of cohabitation, and as a corollary, the role of marriage are different in Scandinavia and the United States, the estimates of marital premia are not always comparable across the settings.

${ }^{16}$ In our analysis, the marital premia for men and women are about $6 \%$ and $2 \%$, respectively (see below). If one in five of single employees are cohabiting, and they earn the same premium as married employees, the bias will be $1.6 \%$ for men and $0.5 \%$ for women: we will estimate the marital premium for men to be $6 \%$ rather than the correct $7.6 \%$ and for women to be $2 \%$ rather than the correct $2.5 \%$. See Light (2004) for cohabitation and marital premia for men and women in the United States.

${ }^{17}$ In panel data one often includes a fixed effect for each individual (e.g., Woodridge 2002), thereby assessing intra-individual differences between years, while above we include fixed effects for the various levels (e.g., occupation-establishment), thereby assessing intralevel (e.g., occupation-establishment) differences between groups of employees (e.g., married vs. single). 
ond empirical puzzle - about the role of sorting on establishments, occupations, and occupation-establishment units - is answered by comparing the changes in estimates from the population level coefficients to the other three levels. Our third empirical puzzle - about the role of family policiesis answered by assessing changes over time in the coefficients at each of the four levels.

The equations are estimated separately for each of the 18 years in the data. We can thus trace changes over time. As explained in the section on family policies, to simplify presentation, we report the averages of the coefficients within each of three distinct family policy periods.

We include both men and women in the analysis and include interaction terms between sex and the other variables: marital status, children, years of education, and potential labor force experience. We center the constant term in each year at the overall mean values of education and potential labor force experience for the 18-year period. The coefficient for being female can then be interpreted as the net sex difference among single and childless employees evaluated at those mean values, controlling for the other variables. At each of the relevant levels - establishment, occupation, and occupation-establishment-we restrict the analyses to units that are sex integrated at the level, simply because we want to assess the gender gap at each level and doing so requires the presence of both sexes at the given level.

The annual coefficients for men being married and for women having children are all significantly different from zero, often with $z$-statistics of 40-50 and significance levels of .000001 . No point is served in focusing on these significance levels; they reflect the large number of observations each year. For some of the other variables, the number of observations gets small (e.g., for widowed) or the coefficients are very small in magnitude and are neither substantively nor statistically significant. For changes over time, each of the 36 comparisons for changes in the motherhood penalty are statistically significant, as are almost all other tests of changes over time, even where substantive sizes of coefficient are stable. The statistical significance of coefficients is reported in the note to the regression table.

The dependent variable is the natural logarithm of the hourly wage. When small (e.g., less than .10 in absolute value), a coefficient can be interpreted as giving the relative change in the unlogged dependent variable from a one-unit increase in the independent variable, holding the other variables constant. We implicitly interpret this as the relative change in the mean of the unlogged wages, but correctly interpreted it gives the relative change in the geometric mean of unlogged wages. ${ }^{18}$

\footnotetext{
${ }^{18}$ Since the equations are estimated separately by year, and the coefficients give relative differences within a year, there is no need to deflate the wage data; results would be unchanged by deflation.
} 
How should one then think about the various estimates we report? It is tempting to assume that the estimates including the most detailed set of fixed effects are the better ones. That is not necessarily the case. A more fruitful way to think about the estimates is that they report on different aspects of the data. No estimates are then necessarily better; they just answer different questions. By comparing changes in coefficients as one goes from the population-level estimates to the occupation- to the occupation-establishment-level estimates one can assess at what levels differences between groups arise: from differential wages at say the occupationestablishment level or from differential sorting of the groups on occupations and occupation-establishment units.

\section{THE GENDER WAGE GAP BY MARITAL STATUS AND CHILDREN}

Table 2 reports the regression coefficients for marital status and children, for men in panel A, for women in panel B, and the differences in coefficients in panel $\mathrm{C}$, for the three different periods for family policies and four different levels, adjusting for education and potential labor force experience. Panel D presents the predicted gender wage gaps for five groups: single, married, and married with one, two, or three or more children, evaluated at the mean level of education and potential labor force experience. ${ }^{19}$

\section{Puzzle 1: Equal Pay for Equal Work by Family Status}

Our first empirical puzzle concerns whether there is equal pay for equal work by family status. The answer to this puzzle is given in the fourth column within each of the three periods, the occupation-establishment (or within-job) estimates (labeled "Occ-Est"). For men (in table 2, panel A), the premia for being married are stable over time $(1.8 \%-2.5 \%)$, and the premia for postmarital states are small and also stable. For children, the premia are smaller and also stable over time, ranging from $0.5 \%$ to $1.1 \%$ for one, two, or three or more children. There is, hence, close to equal pay for equal work: small premia for being married or previously married and even smaller premia for children.

For women (in panel B), in contrast to men, there are sizable declines in penalties and premia over time. The premium to being married in the first period (1979-87) is small at $1.3 \%$, half the male marital premium, and by the last period it is reduced to $0.6 \%$. There are no premia for postmarital

\footnotetext{
${ }^{19}$ In panels A and B of table 2 the results overlap partially with those of two earlier articles, though the specifications and grouping of years are different, the latter now corresponding to three separate family policy periods. Panel A corresponds to panel A in table 3 in Petersen et al. (2011), and panel B to panel A in table 3 in Petersen et al. (2010).
} 


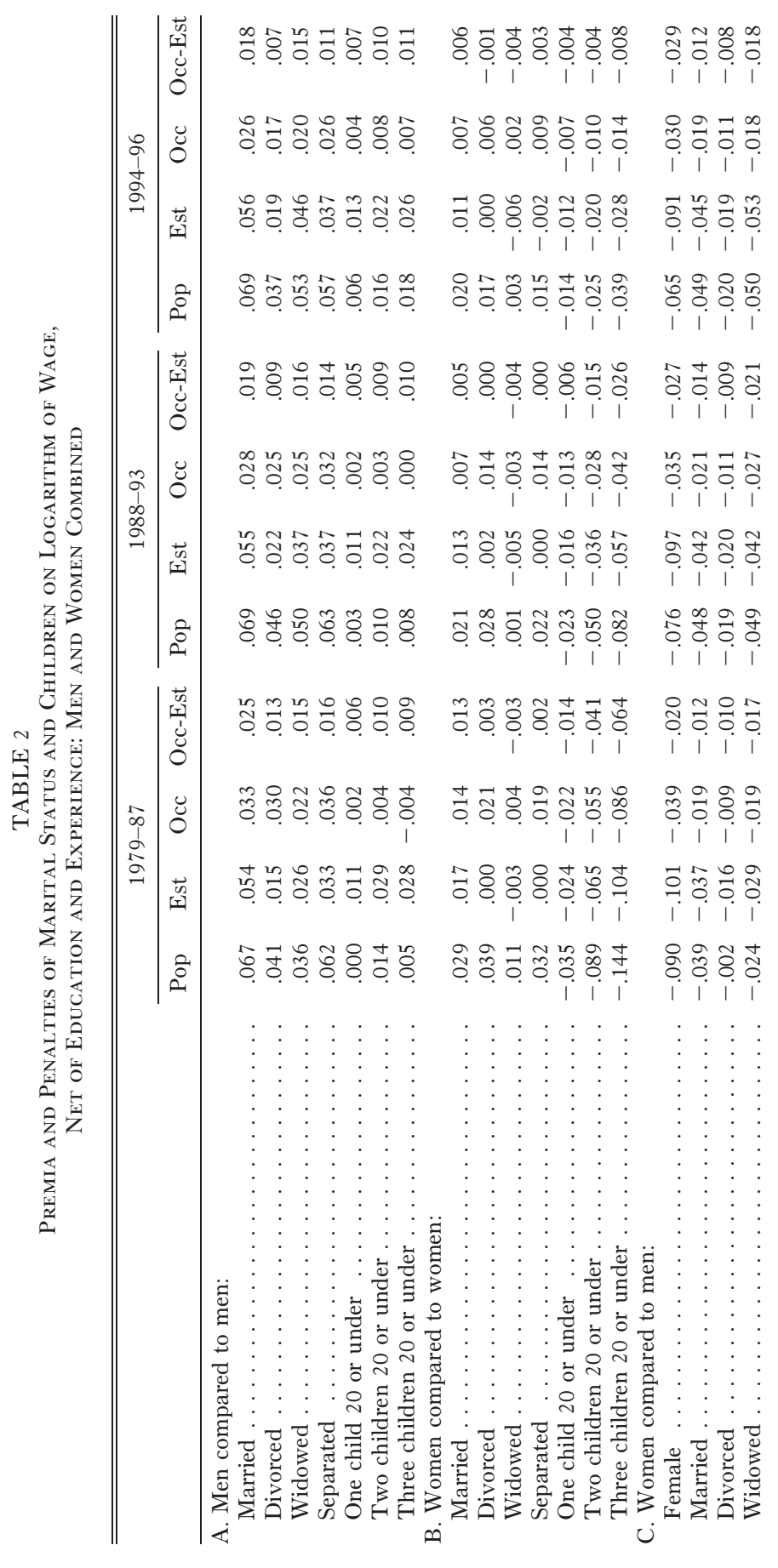




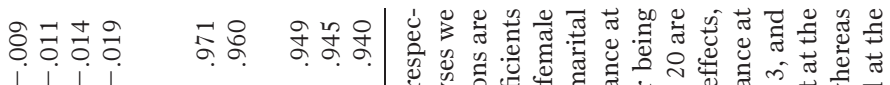

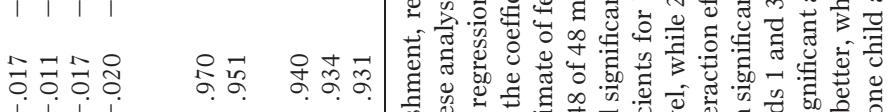

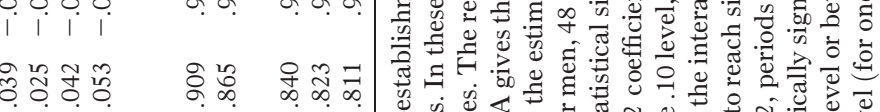

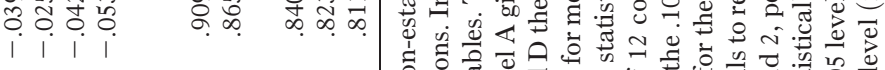
守造字管 i i i 1

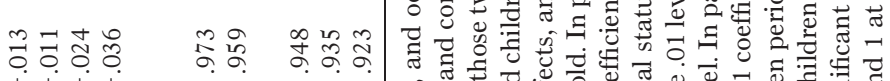

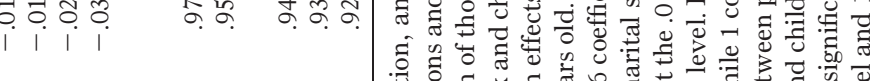

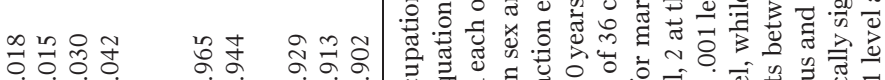
i i i

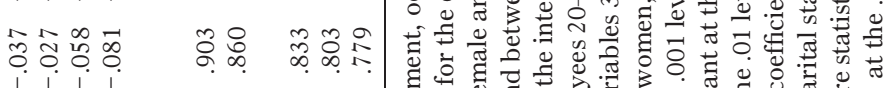
i i i i n क

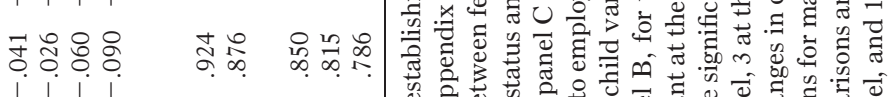

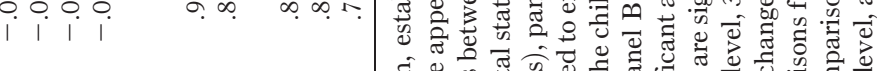

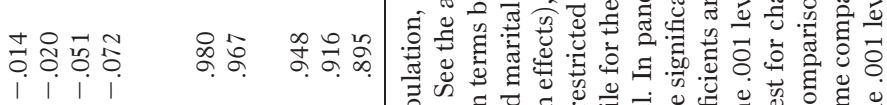
1 1 mo

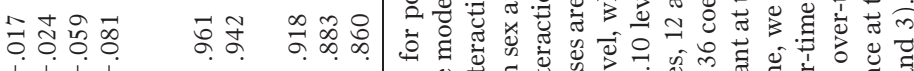
1 1 1 1

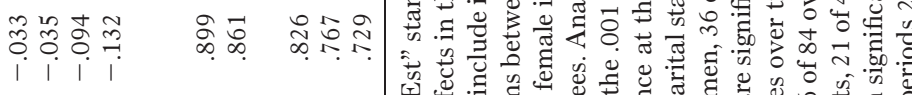

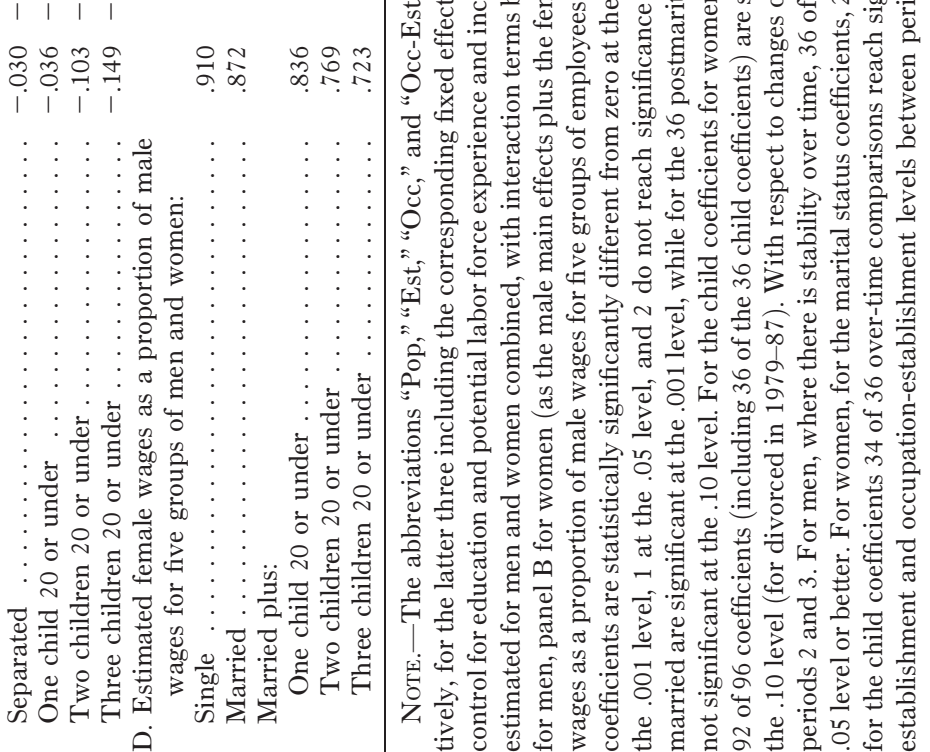


states (unlike for men). For children there are sizable penalties of $1.4 \%$, $4.1 \%$, and $6.4 \%$ for one, two, or three or more children in the first period, which is unequal pay for equal work by motherhood status. These penalties were strongly reduced by the second period (1988-93) and had for all practical purposes vanished by the third (1994-96), with penalties of $0.4 \%, 0.4 \%$, and $0.8 \%$, a situation of virtually equal pay for equal work by motherhood status. The declines in penalties for having two and three or more children were especially pronounced.

Turning to panel C, comparing men and women, since men gain more from marriage than women, marriage increases the gender wage gap by $1.2 \%-1.4 \%$, and postmarital states increase the gap with $0.8 \%-2.1 \%$. From being a parent, men receive minor and stable premia over the entire period, whereas the penalties for women decline. In the first period, having one, two, or three or more children increases the occupation-establishment gender wage gap by $2.0 \%, 5.1 \%$, or $7.2 \%$, whereas in the last period these differentials are $1.1 \%, 1.4 \%$, and $1.9 \%$, dramatically smaller.

Perhaps surprising, there is a negative female main effect (for the reference group single and childless employees), corresponding to a gender wage gap at the occupation-establishment level of $2.0 \%, 2.7 \%$, and $2.9 \%$ in the first, second and third periods, amounting to unequal pay for equal work among single and childless employees. In the first period, this penalty was much smaller than the differentials induced by parental status for two and three or more children, but in the last period, the negative female main effect is larger than the differentials induced by marital status and by having one, two, or three or more children.

The impact of these differentials on the gender wage gap is given in panel $\mathrm{D}$. The gaps at the occupation-establishment level for having 1 child are stable over time, whereas between the first and last period the gender wage gap between married men and women with two or three or more children fell strongly. For example, comparing men and women who are married and have $3+$ children, in the first period women earned only $89.5 \%$ of what men earned in the same job, but by the last period this had risen to $94 \%$, after major family policies had been put in place. It is noteworthy that in the last period the differential in the marital premium does as much to the gender wage gap as the differential in premia and penalties to parenthood, and the negative female main effect increases the gap more than marital and parental status do. The problem in the last period is not that women lose from having children, as the penalties are small at the occupation-establishment level. The problem is that men gain first from being men (most important), second from marriage, and third slightly from fatherhood (least important).

In summary, then, for women there is by the end of the period of our data for all practical purposes equal pay for equal work by motherhood 
and by marital status (differentials are less than $1 \%$ ). For men there is a small premium to being married, even smaller premia for children, and close to equal pay for equal work. The sex differential in premia for marriage adds about $1.0 \%$ to the occupation-establishment level gender wage gap, and the sex differential in premia and penalties for children adds $1.1 \%-1.9 \%$ to the gaps. With respect to equal pay for equal work, by the end of the period, it is the negative female main effect that is the key factor in the occupation-establishment level gender wage gap, as this penalty is clearly larger than any differentials induced by marital or parental status.

\section{Puzzle 2: Role of Sorting on Occupations and Establishments}

Our second puzzle concerns the role of sorting of men and women into establishments, occupations, and occupation-establishment units by family status for the population-level wage gaps. The answer to this puzzle is obtained by comparing the population estimates to the establishment, occupation, and occupation-establishment estimates (in table 2, referred to as "Pop," "Est," "Occ," and "Occ-Est," in cols. 1-4 within each period). If the differences within the other three levels are smaller than at the population level, then it is the differential sorting into those levels that accounts for the large population-level gender wage gap.

For men (in panel A), with stable premia over time at all levels, the marital premia observed at the population level are 50\%-75\% due to sorting into higher-paying occupations and occupation-establishment units, while sorting on establishments is not as important. For fatherhood the premia at the population level are already small $(0.0 \%-1.8 \%)$, and little or even none of this is due to sorting on occupations and occupation-establishment units (with premia of $0.6 \%-1.1 \%$ ). Interestingly, the fatherhood premia at the establishment level are larger than at the other levels, indicating that while fathers are sorted into the lower-paying establishments, within establishments they are sorted into the better-paying occupations.

For women (in panel B), the role of sorting on establishments, occupations, and occupation-establishment units is important for both the marital premia and motherhood penalties: about $50 \%-90 \%$ is due to sorting on occupations and occupation-establishment units and about $30 \%-50 \%$ on establishments.

Comparing the female to the male coefficients (panel C), sorting on establishments accounts for very little of the differences ("Pop" and "Est" estimates are similar), whereas sorting into occupations and occupationestablishment units accounts for about $50 \%$ of the differences in coefficients for children in the first period and $75 \%-100 \%$ in the last period and with similar impacts on differences by marital status. In conclusion, sorting into occupations and occupation-establishment units plays a central 
role in accounting for the gender wage gap by parental and marital status. This is further demonstrated in panel $\mathrm{D}$, which reports the gender wage gaps by family status.

The results establish beyond question that sorting on occupations and establishments is important for explaining the premia and penalties. What is more difficult to assess is whether the sorting occurs due to discrimination in hiring and promotions, to selectivity with higher productivity leading to higher paying positions, or to employee adaptations in terms of where to work. From two separate analyses, it is clear that about a third of the male premium to marriage occurs even prior to marriage, in that men who later become married also earn higher wages while single (Petersen et al. 2011, table 4), suggesting that part of the premia arises due to productivity differences. But some part of this premarital premium is likely due to adaptations with men seeking better-paying positions in anticipation of marriage. The premarital premium is at zero about 15 years before marriage (with marital status measured through 2005, 10 years beyond the wage data). It then increases $0.5 \%$ per year until marriage occurs and reaches its largest value the year before marriage at $7.5 \%$ (Petersen et al. 2011, p. 298, n. 11) ${ }^{20}$ Similarly, women who become mothers earn somewhat lower wages also when they are childless, which may point to elements of selectivity or adaptations also in the motherhood penalty (Petersen et al. 2010, table 3) but alternatively may reflect that women whom employers expect to get married are not hired or promoted at same rates as other women.

\section{Puzzle 3: Role of Family Policies}

Our third puzzle concerns the potential role of family policies for the premia and penalties, which we answer by tracing changes in coefficients across the three periods for each the four levels (Pop, Est, Occ, and Occ-Est). The two key columns are the population level and the occupation-establishment level, addressing, respectively, wage differences in the market and whether there is equal pay for equal work.

As already noted, for men (panel A) there is stability in premia at each of the four levels across the three periods (small for being married, even smaller for fatherhood status); hence, there is no discernible impact of policies. For women (panel B), in contrast, there are sizable changes over the period, small declines in the premia to marriage and major declines in the penalties to children. The marital premia declined at each of the four levels; for being married from $2.9 \%$ to $2.0 \%$ at the population and from $1.3 \%$

\footnotetext{
${ }^{20}$ Very similar results, with somewhat larger premarital premia, are reported for the United States in Dougherty (2006, table 3).
} 
to $0.6 \%$ at the occupation-establishment level. The child penalties were stable in two periods (1980-87 and 1994-96) but declined the first year after the Gender Equality Act of 1978 was made effective (from 1979 to 1980) and then declined precipitously in the second period (1988-93). These changes bear elaborating. Table 3 reports by year the coefficients for the child penalties for women. At the population level, penalties were stable in 1979-87 and 1994-96, but during the six years 1988-93 they were reduced by $50 \%$ for one child and $66 \%$ for two and three or more children, for the latter two dropping annually by about 1 and 1.4 percentage points. These were precisely the years during which family policies were extensively expanded, and the drops in penalties were dramatic. At the occupationestablishment level the penalties were again stable in the years 1979-87 and 1994-96 but then dropped dramatically in the years 1988-93: the penalties for one, two, and three or more children dropped from $1.0 \%$, $3.3 \%$, and $5.3 \%$ in 1987 to $0.3 \%, 0.6 \%, 1.0 \%$ to 1994 .

The key lesson then is that the period with extensive expansion of family policies did practically nothing to change husband and fatherhood premia. However, it reduced slightly the female marital premium and reduced in a perhaps unprecedented manner the penalty to motherhood. The decline in the motherhood penalties — at all levels — over a short period is close to sensational.

The results are elaborated in figure 1. We plot by year a subset of the premia and penalties. Above the horizontal zero-line, we see the stable male marital premium at the population level (with smaller but stable premia at the occupation-establishment level, not plotted). Below the zero-line, we see the negative female main effect and the motherhood penalty to three or more children at both the population and occupation-establishment levels. We see the sharp decline in the motherhood penalty, and the relatively stable female main effect, a penalty that hardly changed after 1990. At the beginning of the period, the negative female main effect was smaller than the penalty to having three or more children at both the population and occupation-establishment levels. But by 1991, the negative female main effect was larger than the motherhood penalty at both levels.

Returning to table 2, for the population-level gender wage gap, the role of being married increases slightly over the period, since male premia are unchanged while female premia declined somewhat, ceteris paribus resulting in an increase in the gender wage gap (panel C). But the population level female main effect declined, ceteris paribus resulting in a decrease in the gender wage gap. The net result is that the gender wage gap among married and childless men and women was relatively stable, with only a small decline (see panel D). It is in the penalties for children that the major changes occurred. From panel C, we see that there is a precipitous drop in the difference between fatherhood premia and motherhood penalties from 


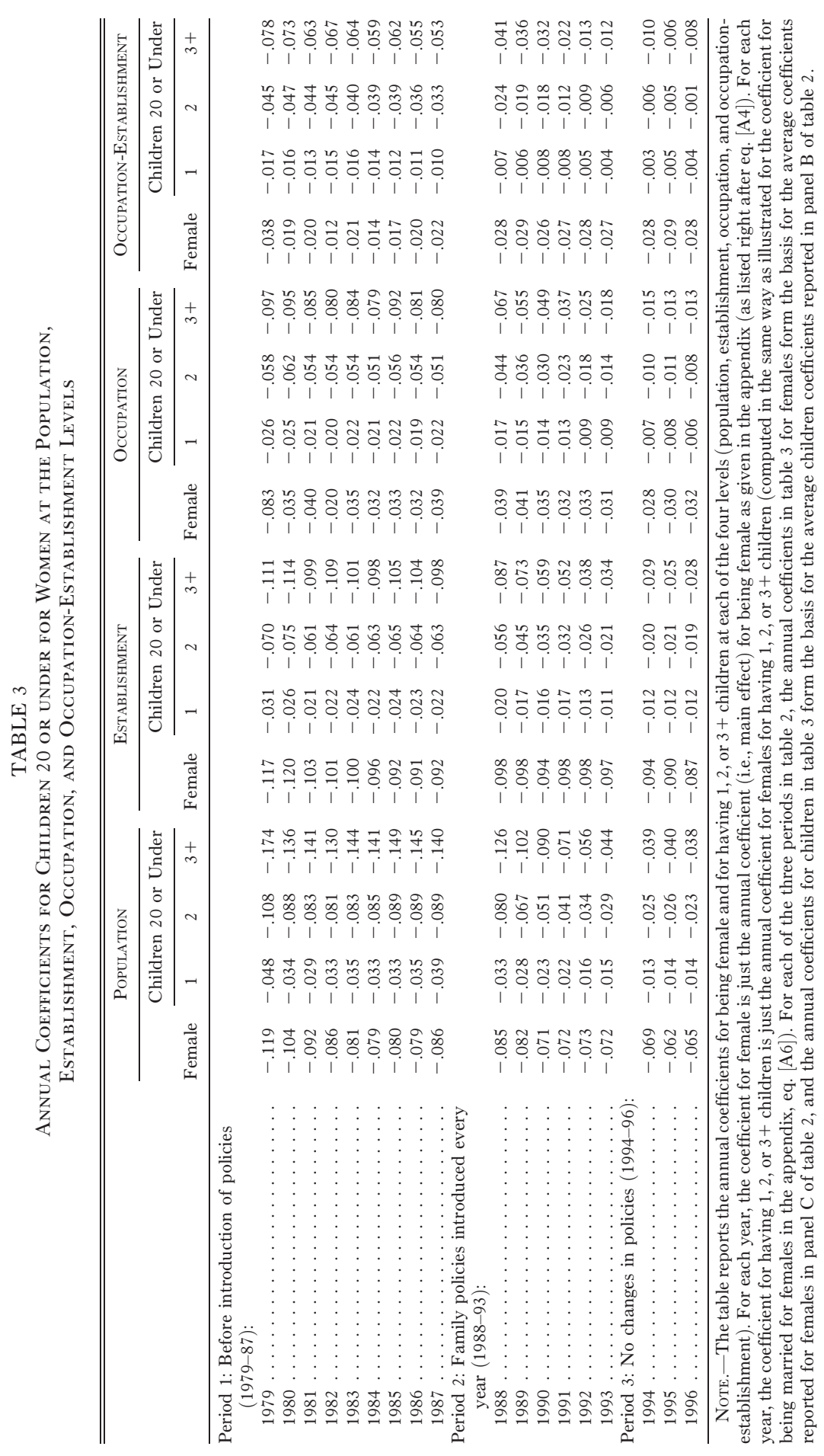


Gender Equality and Family Policy

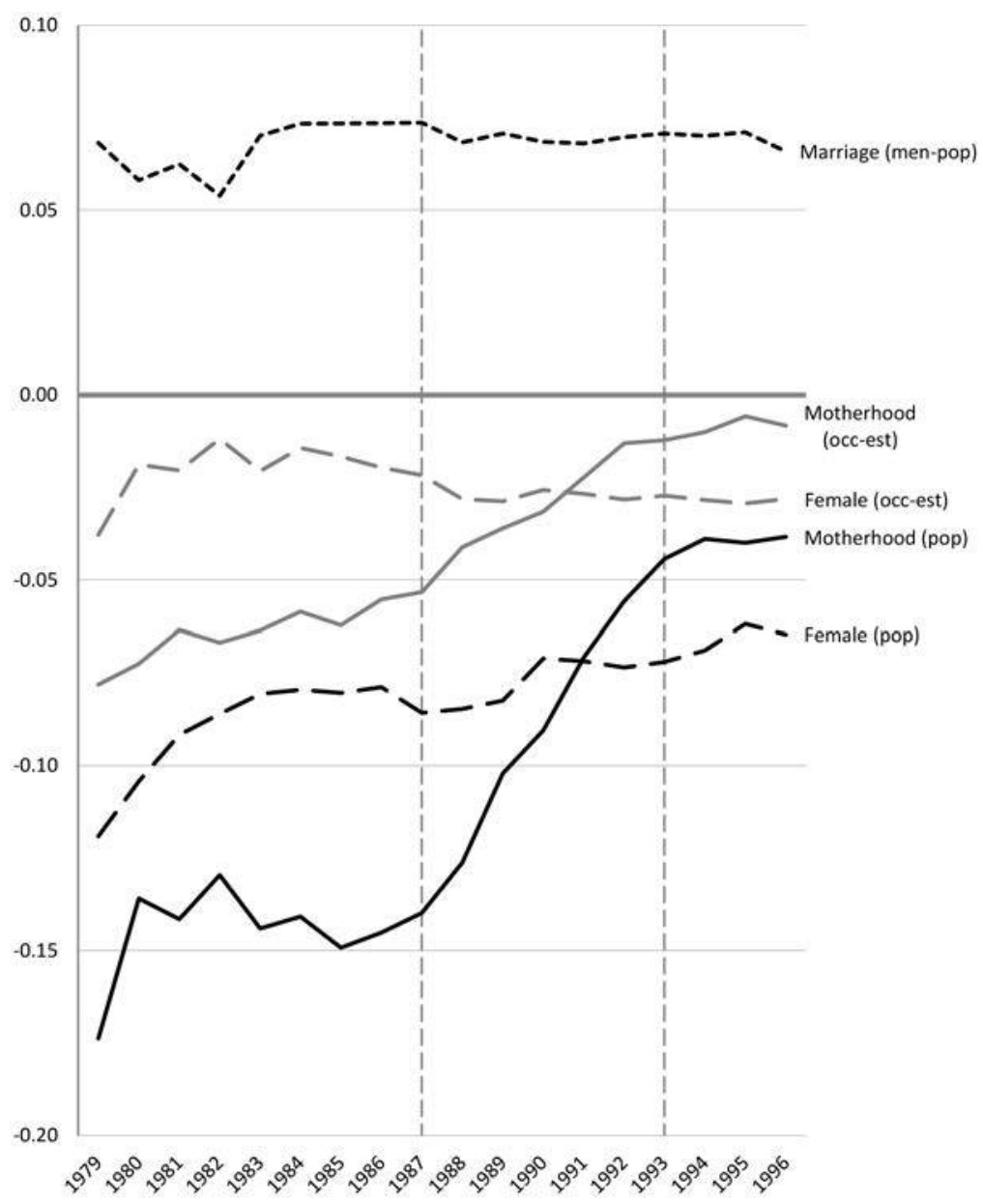

FIG. 1.-Graphs by year for male marital premium (population level), female penalty (population and occupation-establishment levels), and motherhood penalty for three or more children (population and occupation-establishment levels).

the first to the third period, after the introduction of major family policies in the second period. This is especially pronounced for two and three or more children. At the population level in 1979-87, adding one, two, and three or more children, men increased their wages with about $0.0 \%, 1.4 \%$, and $0.5 \%$, women decreased theirs with $3.5 \%, 8.9 \%$, and $14.4 \%$, thus increasing the gap to $16.4 \%, 23.1 \%$, and $27.7 \%$ (or relative wages of $83.6 \%, 76.9 \%$, and $72.3 \%$ ). But by 1994-96, the sizable gaps due to two and three or more children had improved by almost 10 percentage points, to $15.5 \%$ and $18.1 \%$ (or relative wages of $84.5 \%$ and $81.9 \%$ ), a remarkable change. 
There are two notable changes in the composition of men and women with relevance for understanding changes in the overall gender wage gaps, which from table 1 are computed as $30.5 \%$ (1980), $26.0 \%$ (1988), and $20.0 \%$ (1996). The percentage of men who married declined over the period (see table 1), while the premium to being married remained unchanged, which would result in a reduction in the overall gender wage gap. The percentage of women who became mothers increased over the period, while the motherhood penalty decreased, two changes that pull in opposite directions with respect to the overall gender wage gap. The drop in the motherhood penalty was, however, so dramatic that even if all women at the end of the period were mothers, there would still be a decline in the overall gender wage gap.

In conclusion, at the end of the period, the negative female main effect (i.e., the difference between women and men who are single and childless) is larger than the penalty women experience for being a mother, and the sex differences in returns to marital status are at the same magnitude as the sex differences in returns to having children. One may conjecture that family policies had the desired effects and effectively removed the motherhood penalty, but they had less of an effect on the negative female main effect and no effect on premia for husbands and fathers.

\section{CONCLUSION AND DISCUSSION}

\section{Summary}

The processes that occur in the family are today viewed as probably the largest obstacles to continued progress in gender equality in the workplace, with women suffering significant wage and career penalties from motherhood, and men reaping substantial premia to marriage, two diverging processes that combine to increase the wage gap between women and men. For understanding how to ameliorate these processes one needs to identify both where they arise and the potential role of public policies.

Corresponding to the three empirical puzzles outlined in the introduction, we investigated whether the premia and penalties to family status (1) arose from differential pay by employers, (2) arose alternatively from differential sorting of employees on occupations and establishments, and (3) changed over a period when extensive family policies were introduced. Data came from Norway from the years 1979-96, a country and period where public policy made it easier to combine family and career. The clearest first-order impact of the policies is on mothers, but with second-order impacts on fathers through increased pressures to be more active in the family sphere.

We have three main conclusions. For our first puzzle concerning whether there is equal pay for equal work by family status: by the end of the period 
(mid-1990s), when the same work was done for the same employer (i.e., at the occupation-establishment level or same job) there was no motherhood wage penalty. Employers, for all practical purposes, paid the same wages to mothers and nonmothers. At the beginning of the period, the years immediately following the passing of Norwegian Gender Equality Act (1978), the motherhood penalty at the job level was pronounced for women with two and three or more children. The premia for husbands and fathers were stable throughout the entire period and small at the job level. At the end of the period, the penalty from the negative female main effect was larger than the motherhood penalties and the small gender wage gap at the occupation-establishment level was almost unrelated to motherhood status but closely related to being female and the male gain from marriage.

For our second puzzle (a corollary to the first) concerning the role of sorting of men and women into establishments, occupations, and occupationestablishment units by family status: sorting on occupations and occupationestablishment units accounted for $50 \%-75 \%$ of the male marital premia and $50 \%-90 \%$ of the motherhood penalties and, hence, is important for explaining the premia and penalties associated with family status.

For our third puzzle concerning the potential role of family policies for the premia and penalties: there was a major drop in the motherhood penalty from 1979 to the mid-1990s at all levels (population, establishment, occupation, and occupation-establishment), a dramatic change over a relatively short period during which extensive family policies were introduced. At the end of the period, for one, two, and three or more children, the penalties (controlling only for years of education and potential labor force experience) were $1.4 \%, 2.5 \%$, and $3.9 \%$ at the population level and practically zero $(0.4 \%, 0.4 \%, 0.8 \%)$ at the occupation-establishment level. The premia for husbands and fathers remained unchanged at all levels.

Finally, as implied by the third conclusion, by the end of the period the wage gap between men and women arising from family situation did not principally arise from mothers being penalized. The main causes were the rewards men received first from being male and second from marriage. ${ }^{21}$ These rewards have been stable over time, while female penalties to children have dropped. The net effect is a drop in the wage gap between men and women from children, a gap that by the end of the period was practically unrelated to motherhood status at the occupation-establishment level and close to so at the population level. At the beginning of the period analyzed, the motherhood wage penalty was substantial at both the population and occupation-establishment levels. From the data we cannot

${ }^{21}$ It is of course possible that the premium for being male, or conversely the penalty for being female (i.e., the female main effect, pertaining to single and childless employees), arises due to expectations from employers that single childless women will become mothers. 
determine whether the within-job penalty and the differential sorting on occupations and establishment were due to discrimination (in wage setting, hiring, and promotion), to employee selectivity, or due to adaptations in terms of effort and where to work, or some combination thereof.

\section{Discussion}

It seems prudent then to conclude that family policies over a remarkably short historical period have eradicated the motherhood penalty at the occupation-establishment level, with very small residual wage differences, and reduced it by $75 \%$ at the population level - in short, spectacular changes in the motherhood penalty, and as a result a major drop in the gender wage gap. The declines in penalties were extensive in the six years 1988-93, years that coincided with extensive expansion of family policies. It is unlikely that we can ever decisively establish how tight the causal link is between the expanded policies and the vanishing penalties, as there were concurrent changes in family culture and discrimination against women, but the correlation is in all likelihood not coincidental. And since similar changes in family culture occurred also in the United States during this period, but with no comparable change in family policies, and no comparable decline in motherhood penalties from 1975 to 1998 (Avellar and Smock 2003), our confidence in the claim that family policies in part caused the declines is strengthened. Returning to Hakim's (2000, p. 240) claim cited in the introduction that "Nordic egalitarian policies have failed," our conclusions are more optimistic, at least with respect to the wage costs to being a mother. ${ }^{22}$ But family policies have not eradicated the male premia to marriage and children. Nor are they likely to do so in the future. These premia may come from employer discrimination against single and childless men. In part they come from selection among men who become married (cf. Petersen et al. 2011), and we may speculate that they in part are due to increased career aspirations and economic pressures induced by family situation, which in turn may be tied to rational adaptations in the family. Nor have family policies eradicated the negative main effect of being female at the occupation-establishment level, which stood at 2\%-3\% through the entire period. So while the penalty to being a mother has been eradicated, family status still matters for the gender wage gap through the male premium from marriage.

The stability of the male marital premium is perhaps surprising, in that men's contribution to household work has gone up over time, leaving less

\footnotetext{
${ }^{22}$ We provide no analyses of the impact of family policies on female labor force participation (which is high in Scandinavia), nor on changes in occupational sex segregation or on the glass ceiling, both of which appear to be marked in the Scandinavian countries.
} 
time to gain careerwise from household specialization in marriage. In Norway, men's share of total household work and caring for children rose from $30 \%$ to $38 \%$ from 1980 to 2000 , which ceteris paribus might result in a decline in the premium to marriage to the extent that it arises from household specialization. ${ }^{23}$ The stability of the male marital premium is, however, consistent with other findings. In an extensive metanalysis of 50 studies from the United States, the premium dropped every decade during a 30-year period, 1960-90, but was then stable at about $10 \%-12 \%$ for the next two decades, 1990-2010 (Leonard and Stanley 2010). In Sweden, the premium also dropped from the 1960s to the 1980s but was stable between 1980 and 1990 (Richardson 2000).

Countries with extensive family-work policies therefore face a new and probably more intransigent challenge to gender equality: the advantages to husbands and fathers, advantages that may stem from preferential treatment by employers, or from selectivity, or from adaptations of husbands and fathers, or some combination thereof. The extent to which this challenge is solvable is unknown; addressing the problem of male advantage - especially the ways in which employers reward men whose family status changesrequires a different set of policy responses than those policies aimed at facilitating women's careers/work or that address how employers reward mothers and nonmothers. Whether this is a task for public policy can be questioned and, regardless of the answer, will likely engender much disagreement. It is also far from obvious what can be done: one pushes against the limits of governmental intervention, even in highly regulated social democratic societies. In the realm of employee adaptations leading to advantages for fathers and husbands, a core concern is that household specialization may sometimes be good for families and children, though detrimental to gender equality in careers. But were public policy to address more directly the internal adjustments in the family, two places to start would be the division of parental leave between parents and the tax system. Parental leave could be split more evenly between parents, for example, by allocating a third or more of the total leave to fathers. Likewise, perhaps incomes of fathers of small children could be taxed at a higher rate than incomes of mothers? Or perhaps payroll taxes levied on employers could be higher for employing fathers than mothers? Variants of the institution known as protective legislation, which is now practically defunct for women (Wikander, Kessler-Harris, and Lewis 1995), such policies would immediately change the internal bargains in the family. As with many policies, they would likely have myriads of unintended consequences, and while plausible in the Scan-

\footnotetext{
${ }^{23}$ The evidence for the household specialization hypothesis is weak; for the United States see Hersch and Stratton (2000), and for Germany see Pollmann-Schult (2011).
} 
dinavian context, would run counter to the universal character of U.S. policies (e.g., Orloff 2009).

Can we draw any lessons for the prospects for eradicating the family gap in the United States, which along with the United Kingdom has a larger gap than in the Scandinavian (and Nordic) countries? While resources to enact extensive family legislation are plentiful in the United States, political will is lacking, having instead instituted stronger equality legislation enforcement than most other countries. But even with extensive family policies there are features of contemporary U.S. worklife that lead one to a cautious assessment of their possible impact on the family gap.

The first feature is that Americans work longer hours than in most other rich countries, while Norwegians and many Europeans work fewer hours, on average about 1,800 hours per year in the United States versus 1,400 in Norway. The time pressures of careers are less pronounced in Scandinavia than elsewhere. This makes it easier for women to come out on par with men. It also affects men, who often are culturally constrained in terms of how engaged they are expected to be in work and who may also have preferences for lower hours. Moreover, in the United States the long hours intersect with its system of employer-provided benefits and services and create additional dilemmas. The organizations that provide extensive family benefits - such as reduced and/or flexible hours and parental leavealso often employ highly educated and high-earning employees, and these in turn may face penalties in terms of career and wage advancement if they avail themselves of the benefits, due to the pressures on putting in extensive hours at many workplaces (e.g., Glass 2004).

The second feature is that there is more wage inequality in the United States than in Scandinavia, along with lower income taxes. This makes any wage gaps - between the sexes, educational groups, and so on-larger in the United States (Blau and Kahn 1996). The current U.S. system of tax breaks that subsidize child care creates dilemmas. Since child care is more affordable for high-income than it is for low-income families, the benefit is being directed to the employees that need it less. For a given gross child-care cost, the higher-income families with the higher marginal tax rates end up, after the deductions, with the lower net costs.

These two institutional facts - long hours and high wage inequalityare closely interrelated. Since the economic payoff to being in the upper part of the wage distribution is lower in Scandinavia than elsewhere, the incentives for putting in many work hours are also lower, and since the payoff is large at the upper part in the United States and quite low at the bottom, with a premium for long $(50+)$ hours and a penalty for parttime work (since the 1990s), employees at both ends tend to put in many hours of work, at the top because it is so lucrative, at the bottom, when work is available, to make ends meet. The two institutional facts combine 
to create a lower gender gap for both hours worked and earnings among full-time employees in Scandinavia. This has nothing to do with less discrimination from employers but arises from the wage compression in the Scandinavian context.

The institutional facts can work in many directions. On the one hand, high pay or the prospect of high pay provides more incentives for mothers to become professionally successful, as illustrated by the relative lack of women in high occupational positions in Scandinavia compared to the United States (Wright, Baxter, and Birkelund 1995). On the other hand, high pay rarely comes without putting in the requisite hours, and mothers may instead opt out of those jobs. In the United States the former effect seems to dominate. With respect to the role of publicly provided child care, parents in the high-paying jobs are the least in need of it, being able to afford the costs, leaving less room for the impact of family policies. For parents in lower-paying occupations such policies could, however, do wonders.

As a conjecture, an economic system with lower wage inequality, lower work effort, and especially fewer hours may be the most conducive to solving the family gap in pay. These systems are found today in Scandinavia and the Nordic countries, to a lesser extent in continental Europe, and not at all in the United Kingdom and United States. While there is still inequality due to the premia men earn from marriage and the penalty just for being female, the institutional features found in Scandinavia, combined with extensive family policies, contribute to creating equality of treatment (in wages) by motherhood status. In this sense the vanguard for gender equality in labor market outcomes may have shifted from the United States to Northern Europe, where the stalled gender revolution may now be becoming unstalled.

\section{APPENDIX}

\section{Methods}

The subscripts used are as follows: $i$ for individuals, $o$ for occupations, $e$ for establishments, and $t$ for years. The dependent variable is the logarithm of wages $\left(\ln w_{i t}\right)$ for individual $i$ in year $t$, and the independent variables are collected in the vector $x_{i t}$, which includes the constant 1 .

In a cross-sectional analysis, separately for each year $t$ we regress the logarithm of wages $\ln w_{i t}$ on explanatory variables $x_{i t}$, using four different specifications:

$$
\begin{gathered}
\ln w_{i t}=\theta_{P, t} x_{i t}+\varepsilon_{i t}, \\
\ln w_{i t}=\theta_{E, t} x_{i t}+\eta_{e t}+\varepsilon_{i e t},
\end{gathered}
$$


American Journal of Sociology

$$
\begin{gathered}
\ln w_{i t}=\theta_{O, t} x_{i t}+\eta_{o t}+\varepsilon_{i o t}, \\
\ln w_{i t}=\theta_{O E, t} x_{i t}+\eta_{o e t}+\varepsilon_{i o e t},
\end{gathered}
$$

where $\eta_{e t}, \eta_{o t}$, and $\eta_{\text {oet }}$ are fixed effects (i.e., dummy variables) capturing establishment $e$, occupation $o$, and occupation-establishment unit $o e$, and $\varepsilon_{i t}, \varepsilon_{i e t}, \varepsilon_{i o t}$, and $\varepsilon_{i o e t}$ are error terms. The subscripts to the $\theta$ parameters indicate that these are different coefficients, pertaining to different levels, population $(P)$, establishment $(E)$, and so forth.

In each regression, the $\theta$ coefficients and associated variables $x_{i t}$ are made up of several terms. At the population level $\left(\theta_{P, t} x_{i t}\right)$ we have:

$\theta_{P, t} x_{i t}=$

1. $\alpha_{P M 0, t}+$

2. $\beta_{P M 1, t}$ Married $_{i t}+\beta_{P M 2, t}$ Separated $_{i t}+\beta_{P M 3, t}$ Divorced $_{i t}+\beta_{P M 4, t}$ Widower $_{i t}+$

3. $\delta_{P M 1, t}$ OneChild $_{i t}+\delta_{P M 2, t}$ TwoChildren $_{i t}+\delta_{P M 3, t}$ ThreePlusChildren $_{i t}+$

4. $\gamma_{P M 1, t}\left(\operatorname{Edu}_{i t}-\overline{\operatorname{Edu}}\right)+\gamma_{P M 2, t}\left(\operatorname{Exp}_{i t}-\overline{\operatorname{Exp}}\right)+\gamma_{P M 3, t}\left(\operatorname{Exp}_{i t}^{2}-\overline{\text { Exp-squared })}\right.$

5. $\alpha_{P I 0, t}$ Female $_{i t}+$ Female $_{i t} \times$

6. $\left[\beta_{P I 1, t}\right.$ Married $_{i t}+\beta_{P I 2, t} \operatorname{Separated}_{i t}+\beta_{P I 3, t}$ Divorced $_{i t}+\beta_{P I 4, t}$ Widower $_{i t}+$

7. $\delta_{P I 1, t}$ OneChild $_{i t}+\delta_{P I 2, t}$ TwoChildren $_{i t}+\delta_{P I 3, t}$ ThreePlusChildren $_{i t}+$

8. $\left.\gamma_{P I 1, t}\left(\operatorname{Edu}_{i t}-\overline{\operatorname{Edu}}\right)+\gamma_{P I 2, t}\left(\operatorname{Exp}_{i t}-\overline{\operatorname{Exp}}\right)+\gamma_{P I 3, t}\left(\operatorname{Exp}_{i t}^{2}-\overline{\text { Exp-squared }}\right)\right]$,

where lines 1-4 pertain to the main effects for men, line 5 to the main female effect, and lines 6-8 to the interaction effects for being female. The variables Married through Widower, OneChild through ThreePlus Children, and Female are dummy variables for the marital statuses and the number of children and for being female, "Edu," "Exp" and "Expsquared" denote education (in years), potential labor force experience (in years) and potential labor force experience-squared, and $\overline{\operatorname{Edu}}, \overline{\operatorname{Exp}}$, and Exp-squared denote their overall averages (across employees and years).

The associated coefficients are $\beta_{P M 1, t}$ and so forth, where the subscript $P M 1, t$ indicates that this is the coefficient at the population level $(P)$ for men $(M)$ for the first variable (1) for the given year $(t)$, and so on for the other coefficients, giving the main effects for men. The coefficient $\alpha_{P I 0, t}$ gives the main effect for being female, and the coefficients $\beta_{P I 1, t}$ and so forth give the corresponding interaction effects for women.

In table 2 we report the averages of these annual coefficients within each of three periods (1979-87, 1988-93, 1994-96). We give here the details for the coefficient for being married and for the main effect for being female at the population level in the first period, with similar notation for the other coefficients, and with entirely corresponding computations for the coefficients for the establishment, occupation, and occupation-establishment levels, where the subscript $P$ is replaced with the corresponding subscripts at those levels, as in (A2)-(A4) above. 
In table 2, panel A, we report these averages for men. The average coefficient at the population level for men for being married in the first of the three periods is then:

$$
\bar{\beta}_{P M 1,1979-87}=\frac{1}{9} \sum_{t=1979}^{t=1987} \beta_{P M 1, t}
$$

which in table 2 (panel A, col. 1) is reported as .067.

For women, in panel B, we first compute for each year the female effect $\left(\beta_{P F 1, t}\right)$ for being married as the sum of the male main effect and the female interaction effect (in both cases for being married):

$$
\beta_{P F 1, t}=\beta_{P M 1, t}+\beta_{P I 1, t} .
$$

The average coefficient at the population level for women for being married in the first of the three periods is then

$$
\bar{\beta}_{P F 1,1979-87}=\frac{1}{9} \sum_{t=1979}^{t=1987} \beta_{P F 1, t},
$$

which in table 2 (panel B, col. 1) is reported as .029 .

In panel $\mathrm{C}$, we report the average of the female main effects (A8a) and the average of the female interaction effects from being married (A8b), namely, as

$$
\begin{gathered}
\bar{\alpha}_{P I 0,1979-87}=\frac{1}{9} \sum_{t=1979}^{t=1987} \alpha_{P I 0, t}, \\
\bar{\beta}_{P I 1,1979-87}=\frac{1}{9} \sum_{t=1979}^{t=1987} \beta_{P I 1, t},
\end{gathered}
$$

which in table 2 (panel C, col. 1) are reported as -.090 and -.039 .

Finally, in panel $\mathrm{D}$ we report the implied gender wage gaps between women and men who are (1) single and childless, (2) married without children, (3) married with one child, (4) married with two children, and (5) married with three or more children, at the population level as follows in the first of the three periods:

$$
\begin{gathered}
\exp \left(\bar{\alpha}_{P I 0,1979-87}\right) \\
\exp \left(\bar{\alpha}_{P I 0,1979-87}+\bar{\beta}_{P I 1,1979-87}\right), \\
\exp \left(\bar{\alpha}_{P I 0,1979-87}+\bar{\beta}_{P I 1,1979-87}+\bar{\delta}_{P I 1,1979-87}\right),
\end{gathered}
$$


American Journal of Sociology

$$
\begin{aligned}
& \exp \left(\bar{\alpha}_{P I 0,1979-87}+\bar{\beta}_{P I 1,1979-87}+\bar{\delta}_{P I 2,1979-87}\right) \\
& \exp \left(\bar{\alpha}_{P I 0,1979-87}+\bar{\beta}_{P I 1,1979-87}+\bar{\delta}_{P I 3,1979-87}\right)
\end{aligned}
$$

which in table 2 (panel D, col. 1) are reported as .910, .872, .836, .769, and .723. To get the gaps at the three other levels, one just replaces the average coefficients above with the corresponding average coefficients at those levels.

\section{REFERENCES}

Alestalo, Matti, and Stein Kuhnle. 1987. "The Scandinavian Route: Economic, Social, and Political Developments in Denmark, Finland, Norway, and Sweden.” Pp. 3-38 in The Scandinavian Model: Welfare States and Welfare Research, edited by Robert Erikson, Erik Jørgen Hansen, Stein Ringen, and Hannu Uusitalo. Armonk, N.Y.: M. E. Sharpe.

Anderson, Deborah J., Melissa Binder, and Kate Krause. 2002. "The Motherhood Wage Penalty: Which Mothers Pay It and Why?" American Economic Review 92 (2): 354-58.

Avellar, Sarah, and Pamela Smock. 2003. "Has the Price of Motherhood Declined over Time? A Cross-Cohort Comparison of the Motherhood Wage Penalty." Journal of Marriage and the Family 65 (3): 597-607.

Bergmann, Barbara R. 2009. "Long Leaves, Child Well-Being, and Gender Inequality." Pp. 67-77 in Gender Equality: Transforming Family Divisions of Labor, edited by Janet Gornick and Marcia K. Meyers. New York: Verso.

Bianchi, Suzanne M., John P. Robinson, and Melissa A. Milkie. 2006. Changing Rhythms of American Family Life. New York: Russell Sage Foundation.

Blau, Francine D., Marianne A. Ferber, and Anne E. Winkler. 2010. The Economics of Women, Men and Work. 10th ed. Upper Saddle River, N.J.: Prentice Hall.

Blau, Francine D., and Lawrence Kahn. 1996. "Wage Structure and Gender Earnings Differentials: An International Comparison.” Economica 63 (suppl.): S29-S62.

Budig, M. J., and P. England. 2001. "The Wage Penalty of Motherhood." American Sociological Review 66 (2): 204-25.

Central Bureau of Statistics. 1991. Lønnstelling. Norges Offisielle Statistikk. NOS C 6. Oslo-Kongsvinger: Statistisk Sentralbyrå.

Cohen, Philip N. 2002. "Cohabitation and the Declining Marriage Premium for Men." Work and Occupations 29 (3): 346-63.

$\rightarrow$ Correll, Shelley J., Stephen Benard, and In Paik. 2007. "Getting a Job: Is There a Motherhood Penalty?” American Journal of Sociology 112 (5): 1297-1338.

Datta Gupta, Nabanita, and Nina Smith. 2002. "Children and Career Interruptions: The Family Gap in Denmark." Economica 69 (3): 609-29.

Datta Gupta, Nabanita, Nina Smith, and Leslie S. Stratton. 2007. "Is Marriage Poisonous? Are Relationships Taxing? An Analysis of the Male Marital Wage Differential in Denmark." Southern Economic Journal 42 (2): 412-33.

Davies, Rhys, and Gaelle Pierre. 2005. "The Family Gap in Pay in Europe: A CrossCountry Study." Labour Economics 12 (4): 469-86.

Dex, Shirley, and Heather Joshi. 1999. "Careers and Motherhood: Policies for Compatibility." Cambridge Journal of Economics 23 (5): 641-59.

Dougherty, Christopher. 2006. "The Marriage Premium as a Distributed Fixed Effect." Journal of Human Resources 41 (2): 433-43.

Ellingsæter, Anne Lise, and Lars Gulbrandsen. 2003. Barnehagen-fra selektivt gode til universelt velferdsgode. NOVA Report 24/2003. Oslo: NOVA. 
Ellingsæter, Anne Lise, and Arnlaug Leira. 2006. "Introduction: Politicising Parenthood in Scandinavia" (Introduction). Pp. 1-24 in Politicising Parenthood in Scandinavia, edited by Anne Lise Ellingsæter and Arnlaug Leira. Bristol: Policy Press.

Esping-Andersen, Gøsta. 1999. Social Foundations of Postindustrial Economies. New York: Oxford University Press.

$\rightarrow$ Fuwa, Makiko. 2004. "Macro-Level Gender Inequality and the Division of Household Labor in 22 Countries." American Sociological Review 69 (4): 751-67.

Gerson, Kathleen. 1985. Hard Choices: How Women Decide about Work, Career, and Motherhood. Berkeley and Los Angeles: University of California Press.

$\rightarrow$ Glass, Jennifer. 2004. "Blessing or Curse? Work-Family Policies and Mother's Wage Growth." Work and Occupations 31 (3): 367-94.

Gornick, Janet C., and Marcia K. Meyers. 2003. Families That Work: Policies for Reconciling Parenthood and Employment. New York: Russell Sage Foundation. 2009. "Institutions That Support Gender Equality in Parenthood." Pp. 3-64 in Gender Equality: Transforming Family Divisions of Labor, edited by Janet Gornick and Marcia K. Meyers. New York: Verso.

$\rightarrow$ Greenwald, Anthony G., and Linda Hamilton Krieger. 2006. "Implicit Bias: Scientific Foundations." California Law Review 94 (4): 945-67.

$\rightarrow$ Groshen, Erica L. 1991. "The Structure of the Female/Male Wage Differential: Is It Who You Are, What You Do, or Where You Work?” Journal of Human Resources 26 (3): $457-72$.

Hakim, Catherine. 2000. Work-Lifestyle Choices in the 21st Century. New York: Oxford University Press.

$\rightarrow$ Hardoy, Inés, and Pål Schøne. 2008. "The Family Gap and Family Friendly Policies: The Case of Norway." Applied Economics 40 (22): 2857-71.

Harkness, S., and J. Waldfogel. 2003. "The Family Gap in Pay: Evidence from Seven Industrialized Countries." Pp. 369-413 in Worker Well-Being and Public Policy, edited by Solomon Polachek. Special issue of Research in Labor Economics, vol. 22 .

Hersch, Joni, and Leslie S. Stratton. 2000. "Household Specialization and the Male Marriage Premium." Industrial and Labor Relations Review 54 (1): 78-94.

Hewlett, Sylvia Ann. 2002. Creating a Life: Professional Women and the Quest for Children. New York: Talk Maramax Books.

$\rightarrow$ Hook, Jennifer L. 2006. "Care in Context: Men's Unpaid Work in 20 Countries, 19652003.” American Sociological Review 71 (4): 639-60.

$\rightarrow$ Hundley, Greg. 2000. "Male/Female Earnings Differences in Self-Employment: The Effects of Marriage, Children, and the Household Division of Labor." Industrial and Labor Relations Review 54 (1): 95-114.

Kitterød, Ragnhild H., and S. V. Pettersen. 2006. "Making Up for Mothers' Employed Working Hours? Housework and Childcare among Norwegian Fathers." Work, Employment and Society 20 (3): 473-92.

Knudsen, Knud, and Kari Wærness. 2008. "National Context and Spouses' Housework in 34 Countries.” European Sociological Review 24 (1): 97-113.

Korenman, Sanders, and David Neumark. 1991. "Does Marriage Really Make Men More Productive?" Journal of Human Resources 26 (2): 282-307.

$\rightarrow$. 1992. "Marriage, Motherhood, and Wages?" Journal of Human Resources 27 (2): $233-55$.

Leira, Arnlaug. 2002. Working Parents and the Welfare State: Family Change and Policy Reform in Scandinavia. New York: Cambridge University Press.

Leonard, Megan de Linde, and T. D. Stanley. 2010. "Is There a Male Marriage Wage Premium? A Meta-Regression Analysis.” Working paper. Hendrix College.

$\rightarrow$ Light, Audrey. 2004. "Gender Differences in the Marriage and Cohabitation Income Premium.” Demography 41 (2): 263-84. 
American Journal of Sociology

$\rightarrow$ Noack, Turid. 2001. "Cohabitation in Norway: An Accepted and Gradually More Regulated Way of Living." International Journal of Law, Policy and the Family 15 (1): $102-17$.

NOU. 1991. Mannsrolleutvalgets sluttrapport [Committee on men's role final report]. Norges Offentlige Utredninger 1991: 3. Oslo: Statens Forvaltningstjeneste.

- 1995. Pappa kom hjem [Daddy come home]. Norges Offentlige Utredninger 1995: 27. Oslo: Statens Forvaltningstjeneste.

Orloff, Ann Shola. 2009. "Should Feminists Aim for Gender Symmetry? Why a DualEarner/Dual-Caregiver Society Is Not Every Feminist's Utopia." Pp. 129-57 in Gender Equality: Transforming Family Divisions of Labor, edited by Janet Gornick and Marcia K. Meyers. New York: Verso.

$\rightarrow$ Petersen, Trond, and Laurie Morgan. 1995. "Separate and Unequal: OccupationEstablishment Segregation and the Gender Wage Gap.” American Journal of Sociology 101 (2): 329-65.

Petersen, Trond, Andrew Penner, and Geir Høgsnes. 2010. "The Within-Job Motherhood Wage Penalty in Norway, 1979-1996." Journal of Marriage and the Family 72 (5): 1274-88.

- 2011. "The Male Marital Premium: Sorting versus Differential Pay.” Industrial and Labor Relations Review 64 (2): 283-304.

$\rightarrow$ Petersen, Trond, Vemund Snartland, Lars-Erik Becken, and Karen M. Olsen. 1997. "Within-Job Wage Discrimination and the Gender Wage Gap: The Case of Norway." European Sociological Review 15 (2): 199-215.

Pollmann-Schult, Matthias. 2011. "Marriage and Earnings: An Investigation into the Causes of the Male Marriage Wage Premium.”European Sociological Review 27 (2): 147-63.

Presser, Harriet B. 1995. "Are the Interests of Women Inherently at Odds with the Interests of Children or the Family? A Viewpoint." Pp. 297-319 in Gender and Family Change in Industrialized Countries, edited by Karen Oppenheim Mason and AnMagritt Jensen. New York: Oxford University Press.

Richardson, Katarina. 2000. "The Evolution of the Marriage Premium in the Swedish Labor Market, 1968-1991.” Manuscript. Office of Labor Market Policy Evaluation, Uppsala.

Rodgers, William M., III, and Leslie S. Stratton. 2010. "The Male Marital Wage Differential: Race, Training, and Fixed Effects." Economic Inquiry 48 (3): 722-42.

$\rightarrow$ Rønsen, Marit, and Marianne Sundström. 2002. "Family Policy and After-Birth Employment among New Mothers - a Comparison of Finland, Norway and Sweden." European Journal of Population 18 (2): 121-51.

$\rightarrow$ Stratton, Leslie S. 2002. "Examining the Wage Differential for Married and Cohabiting Men.” Economic Inquiry 40 (2): 199-212.

$\rightarrow$ Waldfogel, Jane. 1998a. "The Family Gap for Young Women in the United States and Britain: Can Maternity Leave Make a Difference?” Journal of Labor Economics 16 (3): $505-545$.

$\rightarrow$. 1998b. "Understanding the 'Family Gap' in Pay for Women with Children." Journal of Economic Perspectives 12 (1): 137-156.

Wikander, Ulla, Alice Kessler-Harris, and Jane Lewis, eds. 1995. Protecting Women: Labor Legislation in Europe, the United States, and Australia, 1880-1920. Urbana: University of Illinois Press.

Williams, Joan C. 2010. Reshaping the Work-Family Debate: Why Men and Class Matter. Cambridge, Mass.: Harvard University Press.

Wooldridge, Jeffrey M. 2002. Econometric Analysis of Cross Section and Panel Data. Cambridge, Mass.: MIT Press.

$\rightarrow$ Wright, E. O., J. Baxter, and G. Birkelund. 1995. "The Gender Gap in Workplace Authority: A Cross-National Study.” American Sociological Review 60 (3): 407-35. 